Supporting Information for:

\title{
In Vivo Degradation and Toxicity of Copper Indium Sulfide Quantum Dots
}

Joshua C. Kays ${ }^{\dagger}$, Alexander M. Saeboe ${ }^{\ddagger}$, Reyhaneh Toufanian ${ }^{\ddagger}$, Danielle E. Kurant ${ }^{\S}$, Allison M. Dennis ${ }^{t, \neq, *}$

${ }^{\dagger}$ Department of Biomedical Engineering, Boston University, Boston, MA 02215.

‡ Division of Materials Science \& Engineering, Boston University, Boston MA 02215.

$\S^{\S}$ Department of Pathology, Brigham and Woman's Hospital, Boston, MA 02215.

Email: aldennis@bu.edu

\section{Contents}

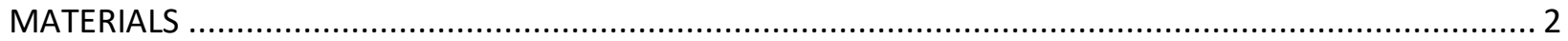

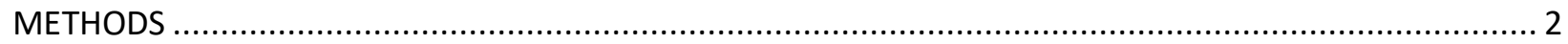

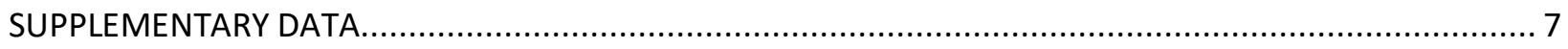

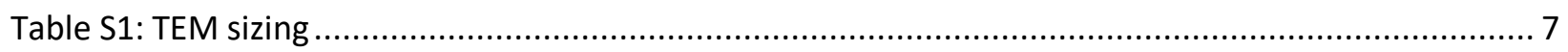

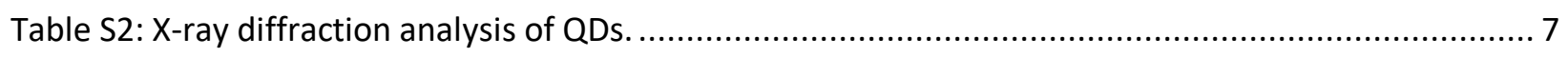

Figure S1: Dynamic light scattering of micelle-encapsulated QDs...................................................... 8

Table S3: DLS-based hydrodynamic diameters of micelle-encapsulated QDs. ...................................... 8

Figure S2: TEM of negatively stained micelle-encapsulated CIS/ZnS QD. ......................................... 9

Table S4: Comparison of ion composition of simulated body fluid and human blood plasma................. 9

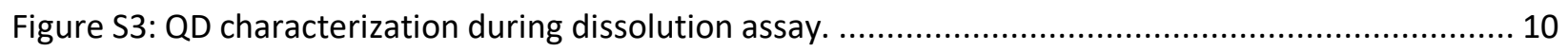

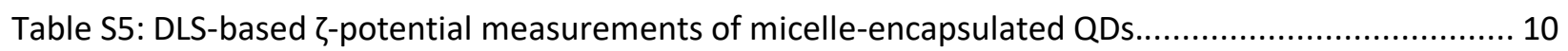

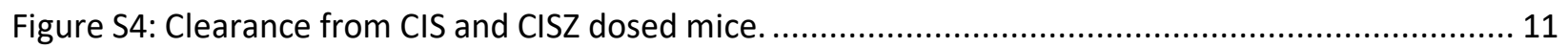

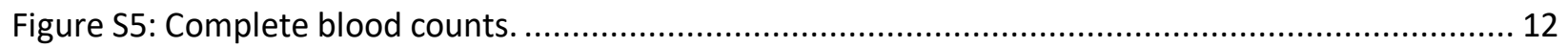

Table S6: Body and organ weights and calculated indexes for individual animals and cohorts............... 13

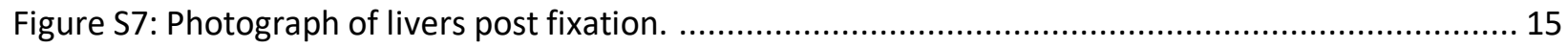

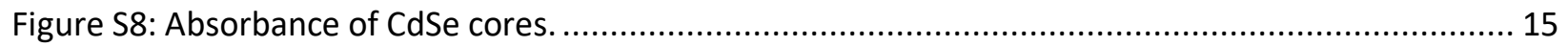

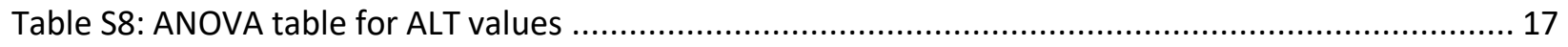

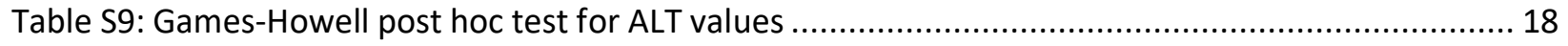

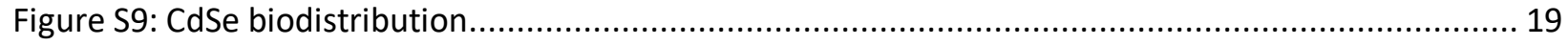

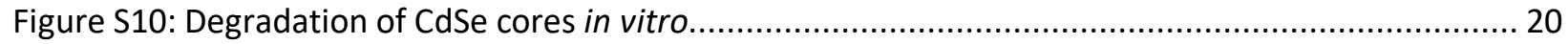

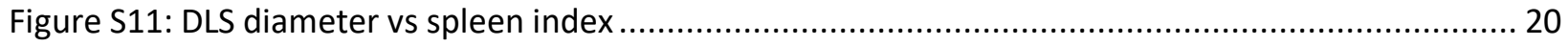

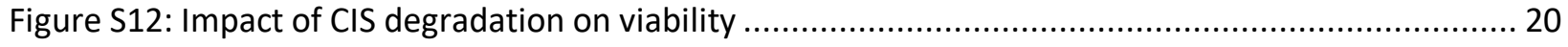

Figure S13: Dose response curve scaled to whole particle concentration ........................................... 20

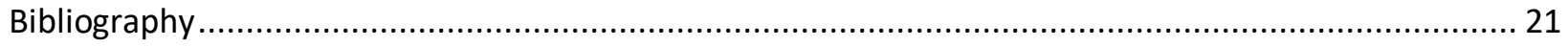




\section{MATERIALS}

Copper(I) iodide (Cul, 99.999\%), trioctylphosphine (TOP, 97\%), zinc stearate (technical grade), hexamethyldisilathiane $\left((\mathrm{TMS})_{2} \mathrm{~S}\right.$, synthesis grade), 1-dodecanethiol (DDT, >=98\%), oleic acid (technical grade, 90\%), 1-octadecene (ODE, technical grade, 90\%), oleylamine (OLA, technical grade, 70\%), methanol (anhydrous, 99.8\%), hydrochloric acid (concentrated), sodium hydroxide (12 M), nitric acid (70\%, TM grade), Calcium chloride dyhydrate, sodium sulfate, sodium bicarbonate, pyruvate, sodium chloride (TM grade), magnesium chloride hexahydrate (BioXtra), potassium chloride (TM grade), and indium (III) acetate $\left(\operatorname{In}(\mathrm{Ac})_{3}, 99.99 \%\right)$ were purchased from Sigma-Aldrich. Potassium phosphate dibasic trihydrate was purchased from A.G. Scientific. Tris (hydroxymethyl) aminomethane (Tris, Molecular biology grade) was purchased from Research products international. Zinc bromide $\left(\mathrm{ZnBr}_{2}, 98 \%\right)$, hexanes (Optima ${ }^{\mathrm{TM}}$ for HPLC, $\left.\geq 99.9 \%\right)$, isopropyl alcohol (99.5\%), and ethanol (anhydrous, histological) were purchased from Fisher Scientific, while carbon tetrachloride (99+\%) and sulfur (refined, 99.5\%) were purchased from ACROS Organics. 1,2-distearoyl-sn-glycero-3-phosphoethanolamine- $\mathrm{N}$-[methoxy(polyethylene glycol)-2000] (ammonium salt) (DSPE-PEG2k) was purchased from Avanti Lipids, Inc. Quartz glass cuvettes were purchased from Starna Cells Inc. All air-sensitive materials were stored and handled in a glovebox under argon atmosphere.

\section{METHODS}

Synthesis of thiol-free CIS cores. CIS quantum dots were synthesized from the literature with modification. ${ }^{1} 1.5 \mathrm{mmol}$ of $\mathrm{Cul}$ and $\mathrm{InCl}_{3}$ were added to a $100 \mathrm{~mL}$ round bottom flask in an argonfilled glovebox, along with $7.5 \mathrm{~mL}$ of TOP, $15 \mathrm{~mL}$ of ODE, and $9 \mathrm{~mL}$ of oleylamine. The flask was added to a Schlenk line and heated to $95^{\circ} \mathrm{C}$ under vacuum until all of the metal salts dissolved. The flask was flushed with argon and heated to $170^{\circ} \mathrm{C}$ before $1.5 \mathrm{mmol}(\mathrm{TMS})_{2} \mathrm{~S}$ in $7.5 \mathrm{~mL}$ ODE was injected, resulting in an immediate color change. The temperature was lowered to $150^{\circ} \mathrm{C}$ for 15 minutes, after which QDs were cooled to room temperature. $2.5 \mathrm{~mL}$ of the raw CIS nanoparticles solution was preserved for further characterization. The remainder of the solution was loaded into a centrifuge tube. A 1:1 ratio of hexanes was added to the solution and the tube was spun at $5000 \mathrm{rpm}$ for 5 minutes to remove aggregates and insoluble excess precursors. The supernatant was transferred into a new tube and anhydrous ethanol was added to the QD solution. The tube was centrifuged at $5000 \mathrm{rpm}$ for 15 minutes to precipitate the QDs. The supernatant was then discarded, and the QDs were resuspended in $16 \mathrm{~mL}$ of degassed ODE. The tube was spun for 5 minutes at $5000 \mathrm{rpm}$ to remove any remaining aggregates, and the supernatant was stored in the glovebox for future use.

Zinc treatment. CISZ QDs were synthesized by annealing the CIS cores described above with zinc, as previously described. ${ }^{1} \mathrm{~A} 100 \mathrm{~mL}$ round bottom flask was loaded with $25 \mathrm{~mL} \mathrm{ODE}, 2.5 \mathrm{~mL}$ TOP, and $1.265 \mathrm{~g}$ zinc stearate. The flask was added to a Schlenk line and heated to $120^{\circ} \mathrm{C}$ until the metal precursor fully dissolved. $4 \mathrm{~mL}$ of the purified CIS QD solution was heated to $120^{\circ} \mathrm{C}$ in an argon-filled $100 \mathrm{~mL}$ round bottom flask. A $5.5 \mathrm{~mL}$ injection of the zinc solution was quickly added to the solution containing the CIS QDs, and the temperature was raised to $150{ }^{\circ} \mathrm{C}$. After 15 minutes, the reaction was stopped by cooling the flask to room temperature. 
Thiol-based core synthesis. $0.4 \mathrm{mmol}$ of Cul, $0.4 \mathrm{mmol} \ln (\mathrm{Ac})_{3}$, and $5 \mathrm{~mL}$ of DDT were loaded into a $100 \mathrm{~mL}$ round bottom flask in an argon-filled glovebox. The flask was added to a schlenk line and degassed for 1 hour at $80^{\circ} \mathrm{C}$ to obtain a clear solution. The temperature was then raised to $230^{\circ} \mathrm{C}$ for 11 minutes to enable particle growth before the reaction was quenched by cooling.

ZnS shell for CIS/ZnS'. $8 \mathrm{~mL}$ of degassed ODE and $0.64 \mathrm{mmol}$ of $\mathrm{ZnBr}_{2}$ were loaded into a $100 \mathrm{~mL}$ round bottom flask in an argon-filled glovebox. The flask was attached to a Schlenk line, placed under vacuum, and heated for 30 minutes at $100^{\circ} \mathrm{C}$. A solution of $4 \mathrm{~mL}$ cleaned, thiol-based CIS QDs, $1 \mathrm{~mL}$ OLA, and $3 \mathrm{~mL} 0.1 \mathrm{M}$ sulfur dissolved in ODE was quickly added to the $\mathrm{ZnBr} 2$ solution. The temperature was raised to $210^{\circ} \mathrm{C}$ and maintained for 2 hours before cooling to room temperature.

Synthesis of CIS/ZnS (for biological experiments). CIS with a thick ZnS shell were synthesized according to the literature, with slight modification. ${ }^{2} 0.2 \mathrm{mmol} \mathrm{Cul}, 0.2 \mathrm{mmol} \mathrm{InCl} 3,2 \mathrm{~mL}$ of trioctylphosphine (TOP), $2 \mathrm{~mL}$ of oleylamine, and $10 \mathrm{~mL}$ of octadecene (ODE) were mixed in a 100 $\mathrm{mL}$ three-neck flask and degassed under vacuum at $70{ }^{\circ} \mathrm{C}$ for $20 \mathrm{~min}$. This solution was then placed under argon and heated to $190^{\circ} \mathrm{C}$. A solution of $0.2 \mathrm{mmol}$ of bis( $\mathrm{N}$-hexyldithiocarbamate) zinc $\left(\mathrm{Zn}(\mathrm{NHDC})_{2}\right)$ dispersed in $1 \mathrm{~mL}$ of TOP was swiftly injected into the flask. The mixture was kept at $190{ }^{\circ} \mathrm{C}$ for $10 \mathrm{~min}$ and then cooled to room temperature. These core nanocrystals were purified by precipitation in ethanol and resuspended in $9 \mathrm{~mL}$ of hexane and $1 \mathrm{~mL}$ of TOP. Growth of the ZnS shell was performed as follows: $2 \mathrm{~mL}$ of core QD solution prepared as described above was mixed with $10 \mathrm{~mL}$ of ODE and $2 \mathrm{~mL}$ of oleic acid. The solution was degassed under vacuum at $70^{\circ} \mathrm{C}$ for $30 \mathrm{~min}$ then heated at $230^{\circ} \mathrm{C}$ under argon. A solution of $0.2 \mathrm{mmol} \mathrm{Zn}(\mathrm{NHDC})_{2}$ and 0.6 mmol zinc stearate in $1 \mathrm{~mL}$ of TOP, $1 \mathrm{~mL}$ of oleylamine, and $8 \mathrm{~mL}$ of ODE was injected dropwise in $20 \mathrm{~min}$. The resulting QDs were then purified after cooling by precipitation in ethanol and acetone and resuspended in hexane.

Synthesis of CdSe cores. CdSe cores were synthesized according to literature. ${ }^{3}$ A $100 \mathrm{~mL}$ threeneck flask with $1 \mathrm{~g}$ of TOPO, $8 \mathrm{~mL}$ of ODE, and $0.38 \mathrm{mmol}$ of $\mathrm{Cd}$-oleate was degassed at room temperature for $30 \mathrm{~min}$, followed by another $30 \mathrm{~min}$ at $80^{\circ} \mathrm{C}$, then backfilled with argon. The temperature was elevated $300{ }^{\circ} \mathrm{C}$, and a solution of $4 \mathrm{mmol}$ of TOP-Se, $3 \mathrm{~mL}$ of oleylamine, and $1 \mathrm{~mL}$ of ODE was quickly injected into the flask to initiate QD nucleation. The temperature was lowered to $270^{\circ} \mathrm{C}$ for $3.5 \mathrm{~min}$, after which the reaction was rapidly cooled to room temperature. Cores were collected by precipitation with ethanol and centrifugation.

Commercial QDs. CIS/ZnS QDs were purchased through Strem chemical (catalogue \#29-8530) and manufactured by UbiQD Inc. CIS cores were custom ordered through UbiQD. In both cases, QDs were resuspended in hexanes, crashed out with ethanol, and incubated in oleic acid and TOP at $50{ }^{\circ} \mathrm{C}$ for 1 hour to replace the native ligands. This process was typically repeated at least once to ensure full exchange of ligands, after which QDs were cleaned $2 x$, and encapsulated as described below.

Precipitation and cleaning of QDs. QDs from the reaction solution were added to hexanes at a 1:1 ratio (volume), and spun down at 21,000 rcf for 2 minutes to remove any precipitates from the reaction. If this pellet was excessively large, $100 \mu \mathrm{L}$ of TOP was added, the solution was 
vortexed, then incubated for $30 \mathrm{~min}$ at $40^{\circ} \mathrm{C}$, after which another spin at 21,000 rcf for 2 minutes was performed. The pellet was discarded, and the supernatant containing the QDs was transferred to a new tube for precipitation with methanol and ethanol. This was spun at 21,000 rcf for 5 minutes, resulting in QD precipitates on the sides and bottom of the tube. The supernatant was discarded, and the pellet was washed with $1 \mathrm{~mL}$ isopropyl alcohol to fully remove excess ligands before the QDs were suspended in the solvent of choice (hexanes, tetrachloride, etc.).

Powder X-Ray Diffraction. XRD was performed on a low background silicon substrate. Cleaned quantum dots suspended in tetrachloride were dropcast on the silicon substrate. Samples were run on a Bruker D8 discovery system run in powder diffraction mode, with $\mathrm{Cu}$ Ka radiation. Detection occurred with 2.2-3.0 second integration times per step at 0.0189-0.0243 degree steps, and spectra were normalized to the maximum peak height.

Transmission Electron Microscopy. TEM images were obtained using a JEOL 2100 system operating at $200 \mathrm{kV}$. Samples were prepared by dripping dilute solutions of QDs in hexanes onto copper TEM grids (Electron Microscopy Services, 400 mesh). The grid was then cleaned with successive washings of hexanes, isopropyl alcohol, ethanol, and deionized (DI) water, and dried at $40{ }^{\circ} \mathrm{C}$ in a vacuum oven for $10 \mathrm{~min}$. TEM images were manually sized using ImageJ software. For solutions of encapsulated QDs, drops of dilute QDs in water were added to fresh grids and washed with DI water repeatedly. After a brief ( $3 \mathrm{~min}$ ) period to dry, Uranyless EM stain was used to provide contrast, stained for 6 min then wicked away with filter paper.

Photoluminescence. Photoluminescence (PL) spectra were recorded with a Nanolog ${ }^{\circledR}$ Spectrofluorometer with a Synapse CCD camera and iHR320 fully automated spectrometer (HORIBA Jobin Yvon). Cleaned QDs were suspended in hexanes and added to a nitric acid cleaned quartz cuvette. Samples were excited at $375 \mathrm{~nm}$ with a $450 \mathrm{~nm}$ long pass filter in front of the emission port, and photoluminescence was corrected for lamp power and detector sensitivity over the wavelength range using correction files, as well as normalized to lamp power.

Encapsulation. QDs were encapsulated in DSPE-PEG2k according to literature, with modification. ${ }^{4}$ Cleaned QDs were suspended in chloroform. DSPE-PEG2k powder (Avanti Lipids Inc) was added to chloroform at a mass ratio of 6:1 DSPE-PEG2k:QD. This solution was evaporated in a pear shape flask heated to $70^{\circ} \mathrm{C}$ on a rotovap, and ultrapure water heated to $70^{\circ} \mathrm{C}$ was added to the flask along with two marbles. The film of particles was evenly dispersed in the water with swirling. The encapsulated QDs were filtered with a $0.1 \mu \mathrm{m}$ syringe filter, and the resulting QDs were concentrated using a $100 \mathrm{kDa}$ centrifugal filter (Millipore). QDs were spun down in $2 \mathrm{~mL}$ tubes at 21,000 rcf for 12-14 hours until a dark QD pellet formed at the bottom. The supernatant was discarded to remove excess DSPE-PEG2k, and the pellet of encapsulated QDs was diluted with $0.9 \%$ saline (TM grade, Sigma Aldrich) in endotoxin-free UP water. QDs were stored in the fridge for < 4 days before injection. To verify if QDs had a low endotoxin content, a representative batch of QDs, handled under identical conditions to QDs dosed in vivo, was tested using a standard Chromogenic LAL Endotoxin Assay Kit (GenScript $\left.{ }^{\circledR}\right)$. Those QDs had measureable (yet low) levels of endotoxin, at $0.21+/-0.02 \mathrm{EU} / \mathrm{mL}$, which would yield a total dose of $0.032 \mathrm{EU}$ per 
mouse (or $1.28 \mathrm{EU} / \mathrm{kg}$ for a $25 \mathrm{~g}$ mouse). For context, this is approximately 4-fold lower than the FDA-recommended human limit of $5 \mathrm{EU} / \mathrm{kg},{ }^{5}$ and mice are far less sensitive to endotoxin burden compared to humans: a previous study showed that mice required a 250 fold higher dose of endotoxin to reach an identical immune response to humans. ${ }^{6}$

In vitro dissolution assay. $10 \mu \mathrm{L}$ of $1 \mathrm{mg} / \mathrm{mL}$ encapsulated QDs in $\mathrm{H}_{2} \mathrm{O}$ were added to $150 \mu \mathrm{L}$ of either water, Simulated Biological Fluid (SBF), or Artificial Lysosomal fluid (ALF) in UltraFlux ${ }^{\circledR}$ iPCR tubes (SSIbio), with quadruplicates. These tubes were heated at $45{ }^{\circ} \mathrm{C}$ in a SimpliAmp Thermal Cycler (Applied Biosystems). Tubes were massed before and after each measurement, so as to correct for any evaporation if it occurred. At each time point, tubes were removed and photos were taken to compare visually. Tubes were briefly vortexed and $1 \mu \mathrm{L}$ was withdrawn to measure absorbance on a Nanodrop spectrophotometer (Thermo Scientific), blanked with either SBF, ALF, or water. Data was analyzed in MATLAB, with spectra normalized to their $\mathrm{t}=0$ absorbance at 400 $\mathrm{nm}$. SBF and ALF were made as previously described ${ }^{7-9}$, using ultrapure (UP) water. Specifically, for SBF, 8.035 grams of sodium chloride, 6.118 grams of tris(hydroxymethyl) aminomethane (Tris), $0.311 \mathrm{~g}$ of magnesium chloride hexahydrate, $0.292 \mathrm{~g}$ of calcium chloride, $0.231 \mathrm{~g}$ of potassium phosphate dibasic trihydrate, $0.225 \mathrm{~g}$ of potassium chloride, and $0.072 \mathrm{~g}$ of sodium sulfate were dissolved in $1 \mathrm{~L}$ of UP water, with $1 \mathrm{~mL} \mathrm{HCl}$ added until pH reached 7.4 (typically 39$41 \mathrm{~mL}$ ). For ALF, 20.8 grams of citric acid, 6.0 grams of sodium hydroxide, $3.210 \mathrm{~g}$ of sodium chloride, 0.179 grams of sodium phosphate monobasic heptahydrate, $0.106 \mathrm{~g}$ of magnesium chloride hexahydrate, $0.039 \mathrm{~g}$ of sodium sulfate, $0.059 \mathrm{~g}$ of glycerin, 0.090 grams of sodium tartrate dehydrate, 0.085 grams of sodium lactate, 0.086 grams of sodium pyruvate, and $1 \mathrm{~mL}$ of formaldehyde were added to $1 \mathrm{~L}$ of UP water. To both SBF and ALF, $0.04 \%$ sodium azide was added as a preservative to prevent bacteria growth.

QD pre-degradation. To pre-degrade QDs for in vitro viability studies, two methods were used. To achieve higher degradation on a quick time-scale, concentrated hydrochloric acid was added to QDs (>3 mg/mL) in ultrapure water to reach dilute acid concentrations $(0.1-0.15 \mathrm{M})$. This solution was incubated for 3-5 hours at $65^{\circ} \mathrm{C}$ until the absorbance was dropped to the desired amount, then was titrated back to neutral with concentrated sodium hydroxide, and 10x PBS was added to ensure a buffered solution at $\mathrm{pH}$ 7.4. For a more mild degradation, QDs were incubated in $100 \mathrm{~nm}$ syringe filtered SBF (without sodium azide) at $45^{\circ} \mathrm{C}$ for 3 days. Typically, $10-15 \mu \mathrm{L}$ of these solutions were added to $100 \mathrm{uL}$ of media for cell studies. Percent of degradation was determined from the change in high energy $(450 \mathrm{~nm})$ absorbance, since the high energy absorbance of colloidal QDs correlates linearly with the concentration of semiconductor units in particle form, regardless of particle size. Indeed, using experimentally determine relationships between particle size and molar extinction coefficient $(\varepsilon)$ for CIS QDs found that $\varepsilon$ scales with QD volume $^{10}$, thus a $50 \%$ drop in absorbance means a $50 \%$ drop in QD volume and thus, $50 \%$ of material being released.

Cell studies. All cell work was carried out on HepG2 cells (product number: HB-8065, Lot number: 70015966) purchased from American Type Culture Collection (ATCC), cultured with ATCCformulated Eagle's Minimum Essential Medium (EMEM, Catalog No. 30-2003) supplemented with $10 \%$ fetal bovine serum (Corning, Premium quality) and cultured at $37^{\circ} \mathrm{C}$ with $5 \% \mathrm{CO}_{2}$. For 
viability studies, cells were plated at $40 \mathrm{k}$ per well densities on a 96 well plate (Thermo Scientific ${ }^{\mathrm{TM}}$ 165306) with $100 \mu \mathrm{L}$ of media. The next day, media was changed and $100 \mathrm{~nm}$ syringe filtered QDs in sterile PBS were added to reach the desired concentration, with never more than $15 \%$ dilution of the media. Control wells were treated with equivalent volumes of PBS buffer. After 24 hours, media was removed, $100 \mu \mathrm{L}$ of PBS were added to each well, and the viability assay (Promega CellTiter-Glo ${ }^{\circledR}$ Luminescent Cell Viability Assay) was carried out according to manufacturer's instructions. Luminescence was read on a Molecular Devices SpectraMax M5 Microplate Reader set to 250 ms integration time, auto gain settings on, collecting all wavelengths.

Animal studies. All animal experiments were performed under the approval of Boston University's Animal Care and Use Committee. 8-week female BALB/cJ mice were ordered from Jackson Laboratories. Mice were injected with QDs suspended in $0.9 \%$ saline (TM grade, Sigma Aldrich) in endotoxin-free ultrapure water, and syringe filtered at $0.1 \mu \mathrm{m}$ immediately before tail vein injection. Mice were monitored post injection to ensure a return to normal behavior.

Mice tails were heated gently with a heat lamp until vasodilation occurred. A sterile $29 \mathrm{G}$ insulin syringe (Excel International) was used to inject $15 \mathrm{mg} / \mathrm{kg}$ dose of QDs. Mice showed no immediate signs of toxicity after injections (within 20-30 min) for injections, unless otherwise noted.

For blood withdrawals, mice were restrained and cheek bleeds were performed with a sterile 5 $\mathrm{mm}$ lancet (Goldenrod Animal Lancet), and blood was collected into $500 \mu \mathrm{L}$ Lithium-Heparin coated blood tube (Strategic Applications Inc), typically 250-500 $\mu \mathrm{L}$. The sample was immediately taken to be analyzed for hematotoxcity.

Mice were then sacrificed by $\mathrm{CO}_{2}$ asphyxiation and organs were dissected out promptly. For histology experiments, organs were immediately placed in neutral buffered formalin and fixed overnight. After fixation, samples were stored in PBS with $0.05 \%$ azide at $4^{\circ} \mathrm{C}$ for $<2$ weeks. Organs were paraffin embedded, sliced, and hematoxylin and eosin stained by the Boston University School of Medicine Pathology Department Experimental pathology core. Multiple levels were taken for each organ. Micrographs were taken on a Nikon Eclipse NiE microscope with a DS-Fi2 CCD Color Camera.

Tissue digest and MP-AES. All glassware was cleaned with TM grade nitric acid before use. Tissue samples were placed into pre-massed 1 dram, 2 dram, or 6 dram glass vials sealed with PTFEcoated screw caps. Samples were massed, and nitric acid was added at a 2:1 (acid:organ), volume/mass ratio. Samples were remassed, and vials were unscrewed a quarter turn to minimize pressure buildup. Samples were first heated to $40^{\circ} \mathrm{C}$ for $30 \mathrm{~min}$ to pre-digest, followed by a $90{ }^{\circ} \mathrm{C}$ treatment for $30 \mathrm{~min}$. Within $5 \mathrm{~min}$ of this second heating step, samples became clear and turned yellowish red. Upon cooling, samples were a yellow color and contained no visible tissue aggregates, though clear fat droplets were visible. 100-200 $\mu \mathrm{L}$ of the digested tissue was diluted in ultrapure water to $5 \%$ acid content. Samples were run on an Agilent 4200 MP-AES with SPS 4 Auto sampler, with each sample run in quadruplicate.

Blood analysis. Blood collected by cheek bleed was immediately analyzed for hematotoxicity by a Hemavet 950FS (Drew Scientific) Auto Blood Analyzer, requiring $20 \mu \mathrm{L}$. The remaining sample 
was spun down at 1000 rcf for 5 min to separate plasma from RBCs. The plasma was immediately frozen and saved for blood biochemistry analysis of all time points simultaneously. $2 \mu \mathrm{L}$ of plasma was used to measure hemoglobin via absorbance.

When all time points had been collected, plasma was defrosted and pipetted into fresh sample cups. Any samples with hemoglobin values over $1.7 \mathrm{~g} / \mathrm{L}$ were excluded due to artificial increases in blood biochemistry levels with moderate $\left(2.0 \mathrm{~g} / \mathrm{L}\right.$ ) to severe hemolysis ${ }^{11}$ (from our 42 samples, only two needed to be excluded). An IDEXX Catalyst Dx Chemistry Analyzer was used to measure AST, ALT, BUN, total protein, albumin, and calcium levels. Samples were diluted when measurements exceeded the linear range of the instrument - as per reference manual for the instrument - or if sample volume was insufficient, though these later dilutions were rare, and never went below the minimum test range for the instrument.

\section{SUPPLEMENTARY DATA}

\section{Table S1: TEM sizing}

\begin{tabular}{cc}
\hline Sample & Diameter $(\mathrm{nm})^{a}$ \\
\hline CIS $^{b}$ & $3.49 \pm 0.41$ \\
CISZ $^{\prime c}$ & $3.41 \pm 0.50$ \\
CIS/ZnS' $^{c}$ & $4.49 \pm 0.75$ \\
CIS/ZnS $^{d}$ & $10.5 \pm 1.5$ \\
\hline
\end{tabular}

${ }^{a}$ Results of manual sizing of TEM images with ImageJ software assuming spherical shape. Means \pm standard deviation of $n=80-140$ particles, depending on the sample.

${ }^{b}$ Thiol-free core preparation.

${ }^{c} \mathrm{CIS} / \mathrm{ZnS}$ ' used for dissolution study shown in Figure 2.

${ }^{d} \mathrm{CIS} / \mathrm{ZnS}$ used for all other studies/figures.

Table S2: X-ray diffraction analysis of QDs.

\begin{tabular}{cccc}
\hline Sample & Peak position $(\boldsymbol{\theta})$ & FWHM $(\boldsymbol{\theta})^{\text {a }}$ & Size $(\mathbf{n m})$ \\
\hline CIS $^{b}$ & 27.65 & 2.83 & 3.02 \\
CISZ $^{\prime}$ & 27.70 & 2.77 & 3.09 \\
CIS/ZnS $^{c}$ & 28.04 & 1.93 & 4.44 \\
CIS/ZnS $^{d}$ & 28.55 & 1.05 & 8.16 \\
\hline
\end{tabular}

${ }^{a}$ Full-width half-maximum (FWHM) of peak used in Scherrer equation.

${ }^{b}$ Thiol-free core preparation.

${ }^{c} \mathrm{CIS} / \mathrm{ZnS}^{\prime}$ used for dissolution study shown in Figure 2.

${ }^{d} \mathrm{CIS} / \mathrm{ZnS}$ used for all other studies/figures. 


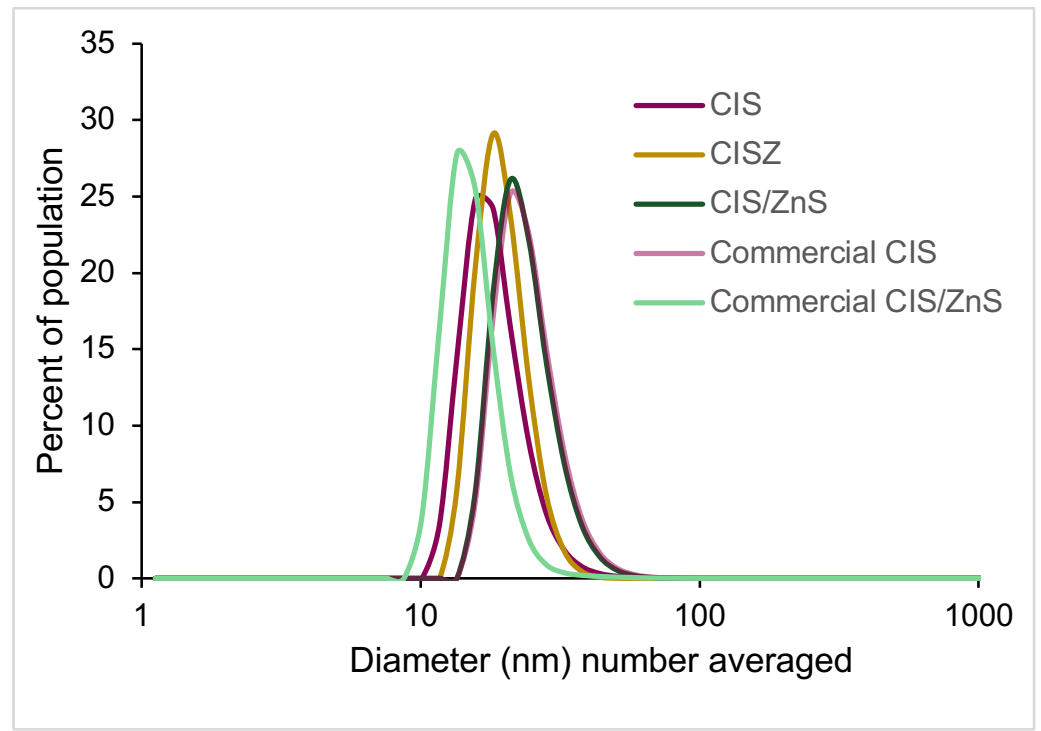

Figure S1: Dynamic light scattering of micelle-encapsulated QDs. Representative trials from the DLS data presented below.

Table S3: Dynamic light scattering-based hydrodynamic diameters of micelle-encapsulated QDs.

\begin{tabular}{cc}
\hline Sample & $\begin{array}{c}\text { Hydrodynamic } \\
\text { Diameter }(\mathbf{n m})^{a}\end{array}$ \\
\hline CIS & $17.1 \pm 1.5$ \\
CISZ & $19.1 \pm 1.3$ \\
CIS/ZnS & $24.2 \pm 0.3$ \\
UbiQD CIS & $25.8 \pm 2.1$ \\
UbiQD CIS/ZnS & $16.3 \pm 3.3$ \\
\hline
\end{tabular}

${ }^{a}$ Number weighted results of $\mathrm{N}=3$ trials of dynamic light scattering (DLS; Malvern ZetaSizer Nano ZS). 


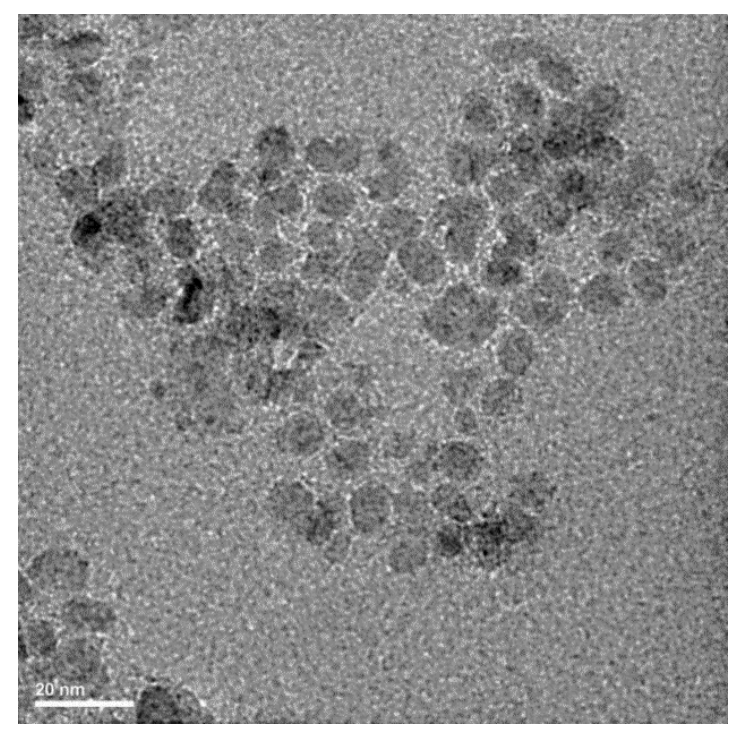

Figure S2: TEM of negatively stained micelle-encapsulated CIS/ZnS QD. The white ring around the QDs indicates the contrast from the negative stain.

Table S4: Comparison of ion composition of simulated body fluid and human blood plasma. Adopted from Marques et al. ${ }^{9}$

\begin{tabular}{|c|c|c|}
\hline Ion & $\begin{array}{c}\text { Simulated Body } \\
\text { Fluid (SBF) } \\
\text { (mM) }\end{array}$ & $\begin{array}{c}\text { Human Blood } \\
\text { Plasma } \\
\text { (mM) }\end{array}$ \\
\hline $\mathrm{HCO}_{3}^{-}$ & 4.2 & 27 \\
\hline$K^{+}$ & 5 & 5 \\
\hline $\mathrm{Cl}^{-}$ & 148.8 & 203 \\
\hline $\mathrm{Na}^{+}$ & 141 & 142 \\
\hline $\mathrm{Ca}^{+2}$ & 2.5 & 2.5 \\
\hline $\mathrm{Mg}^{+2}$ & 1.5 & 1.5 \\
\hline $\mathrm{HPO}_{4}^{-2}$ & 1 & 1 \\
\hline $\mathrm{SO}_{4}^{-2}$ & 0.5 & 0.5 \\
\hline Tris & 50 & 50 \\
\hline Hydrochloric acid & 40 & 45 \\
\hline$p H$ & 7.3 & 7.25 \\
\hline
\end{tabular}


A

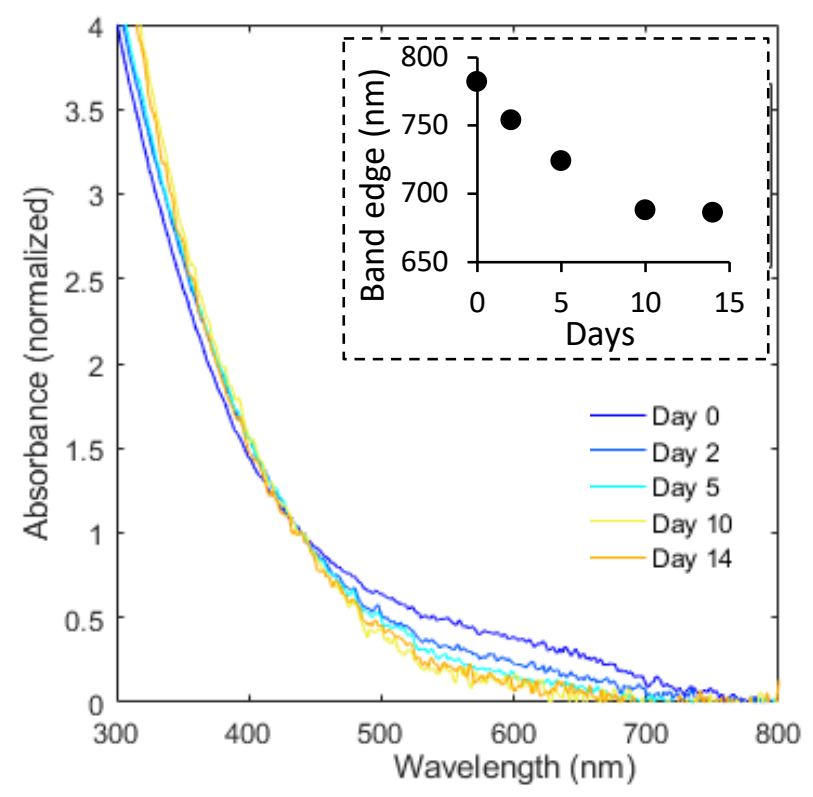

B

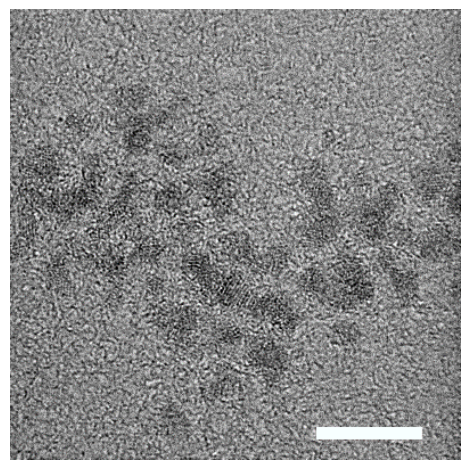

C

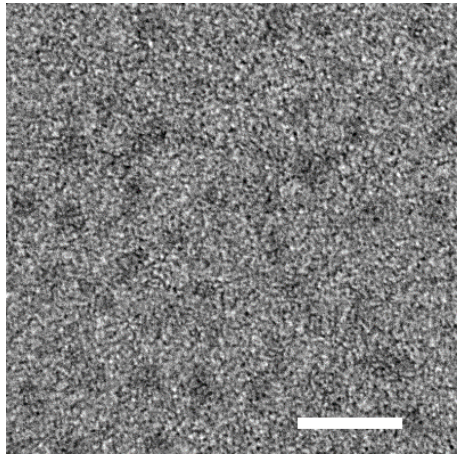

Figure S3: QD characterization during dissolution assay. (A) Absorbance normalized at $400 \mathrm{~nm}$ for CIS samples degrading in water over time. Inset shows the shifting of the band edge over time. (B) CIS QDs before dissolution assay, scale bar $10 \mathrm{~nm}$. (C) Same samples after 10 days of ALF dissolution, scale bar $10 \mathrm{~nm}$. Though quantitative sizing could not be performed due to limited contrast, these samples appear smaller than the QDs in the pre-dissolution images.

Table S5: Dynamic light scattering-based ל-potential measurements of micelle-encapsulated QDs.

\begin{tabular}{|c|c|}
\hline & $\zeta$-potential $(\mathrm{mV})^{a}$ \\
\hline CIS (1) & -0.0834 \\
\hline CIS (2) & 0.258 \\
\hline $\operatorname{CIS~(3)~}$ & -0.446 \\
\hline Mean \pm SD & $-0.090 \pm 0.35$ \\
\hline
\end{tabular}

${ }^{a}$ Three independent measurements of the same sample of DSPE-PEG $2 k$-coated CIS QDs. Empty micelles removed with ultracentrifugation. 
Elemental comparison of in vivo biodegradation. On an organ-level, CIS/ZnS showed persistence in nearly all organs, with no statistical drop in any organ at any time point. For the two degradable QDs (CIS and CISZ), clearance varied between organs: liver and lung clearance were similar between CIS and CISZ, but CIS content in the spleen was statistically decreasing over time ( $p<0.0001$, one-way ANOVA) compared to the statistically unchanged levels in spleens of CISZ-dosed mice ( $p=0.127$, one-way ANOVA). Comparing the two elements, clearance of indium and copper were generally similar for both CIS and CISZ (Figure S4): in four of the six cases (two compositions at the three timepoints), the total copper and indium levels were well correlated within each group (i.e., no statistical difference within pairwise comparisons of copper and indium \% dose persisting). This indicates that they were cleared at similar rates; there is no evidence of one ion becoming preferentially trapped in the tissue or leaching out of an intact particle for more rapid excretion.
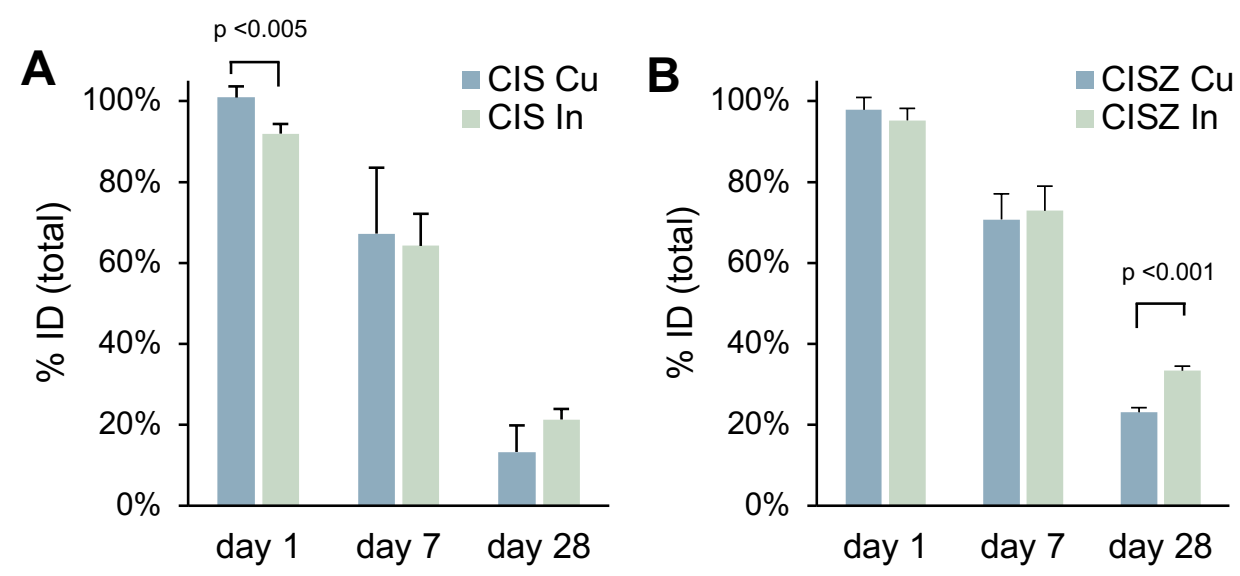

Figure S4: Clearance from CIS and CISZ dosed mice. Percent of initial dose of copper and indium for (A) CIS and (B) CISZ dosed mice. CIS/ZnS copper levels not included here, since the total dose of copper for CIS/ZnS was near physiological background levels. 

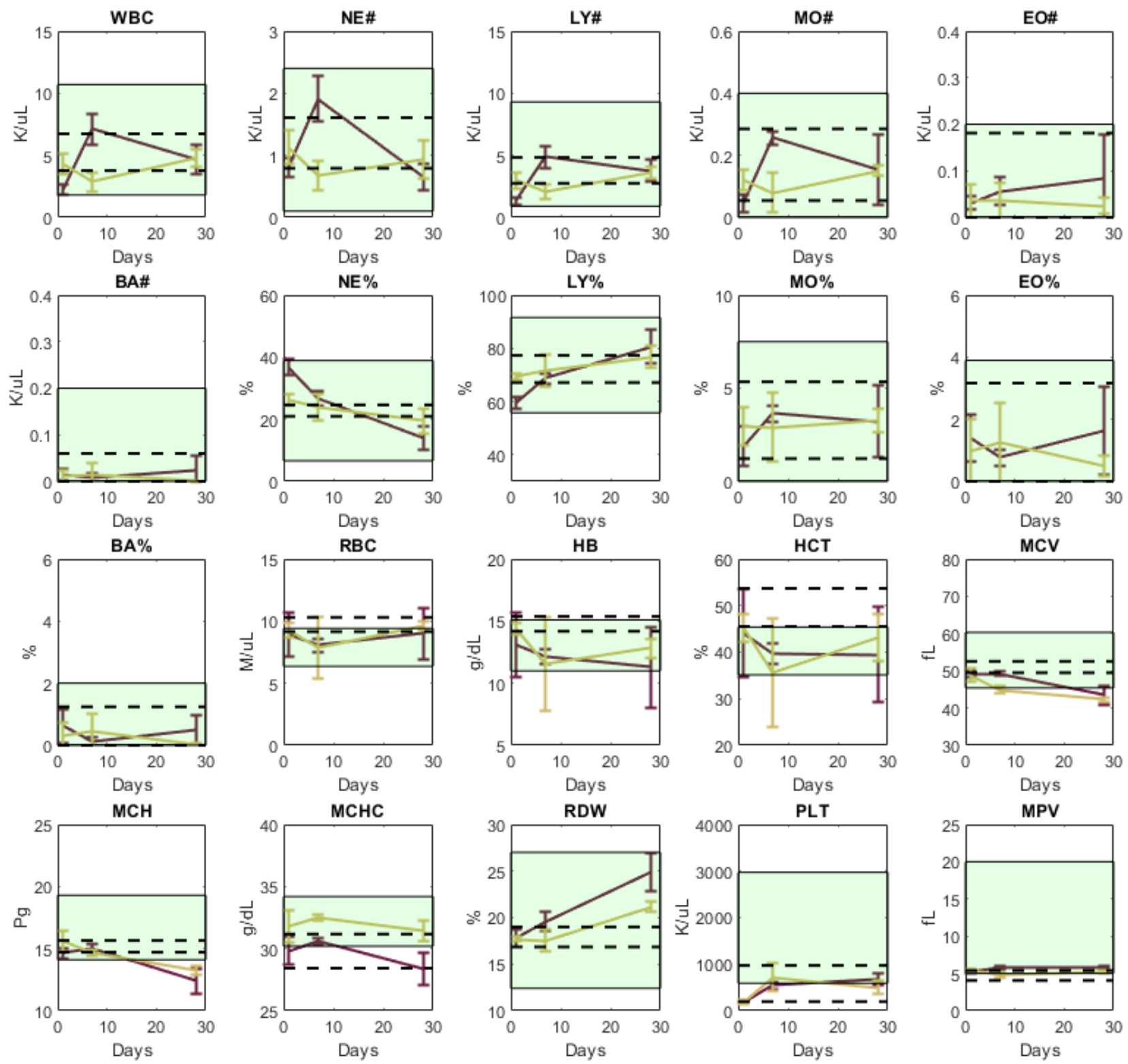

Figure S5: Complete blood counts. Hematotoxicity data from complete blood counts of cheekbled mice. Purple represents CIS dosed mice, yellow represents CISZ, and dashed black lines are two deviations above and below the control means. Green shaded region indicates healthy ranges for mice in vivo, as provided by Hemavet 950 fs software. Nearly all values were within the healthy references ranges for CIS or CISZ, with only PLT (platelet counts) as statistically lower than the reference range at day 1; however, control mice were also below that range. Abbreviations: $\mathrm{WBC}=$ white blood cell, $\mathrm{NE}=$ Neutrophil, $\mathrm{LY}=$ Lymphocyte, $\mathrm{MO}=$ Monocyte, EOS=Eosinophil, $\mathrm{BA}=$ Basophil, $\mathrm{RBC}=$ red blood cell, $\mathrm{HB}=$ Hemoglobin, $\mathrm{HCT}=$ Hematocrit, $\mathrm{MCV}=$ Mean corpuscular volume, $\mathrm{MCH}=$ Mean corpuscular hemoglobin, $\mathrm{MCHC}=$ Mean corpuscular hemoglobin concentration, $\mathrm{RDW}=\mathrm{Red}$ cell distribution width, MPV=Mean platelet volume. 

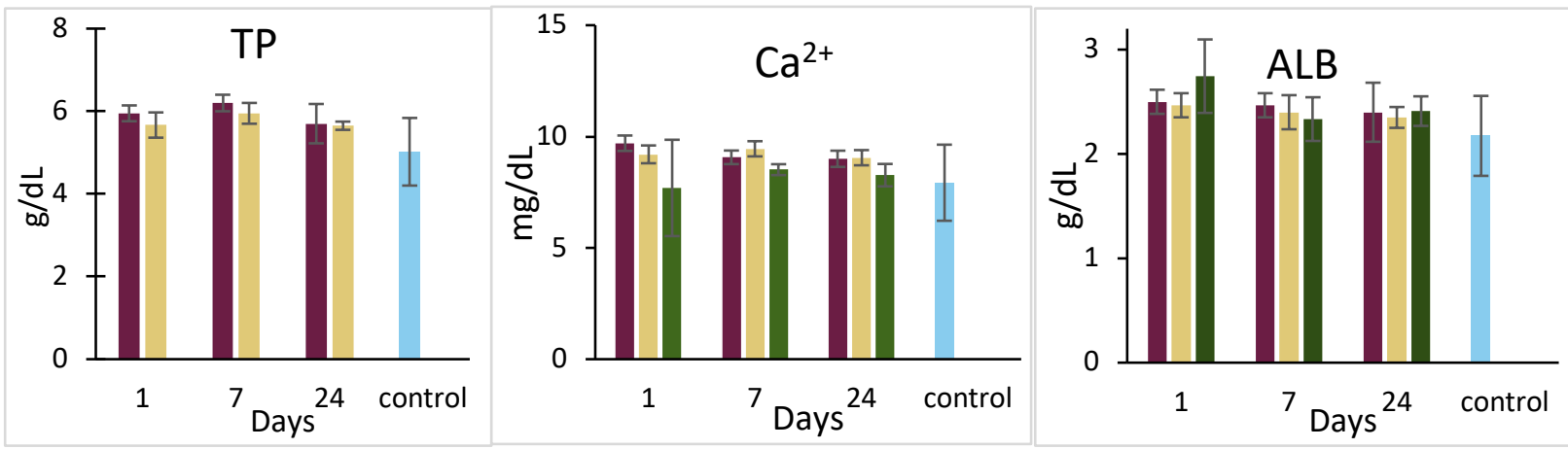

Figure S6: Other serum biochemistry values. Total protein (TP, left), calcium ion $\left(\mathrm{Ca}^{2+}\right.$, center), and albumin (ALB, right) in serum for CIS (purple), CISZ (yellow), and CIS/ZnS (green) dosed mice, compared to controls (blue). There was no difference in these assays compared to controls. TP was not measured for CIS/ZnS.

Table S6: Body and organ weights and calculated indexes for individual animals and cohorts.

\begin{tabular}{|c|c|c|c|c|c|c|c|c|c|}
\hline Mouse cohort & $\begin{array}{c}\text { Body } \\
\text { mass, g }\end{array}$ & $\begin{array}{l}\text { Liver } \\
\text { mass, } \mathrm{g}\end{array}$ & $\begin{array}{l}\text { Liver } \\
\text { index }\end{array}$ & $\begin{array}{l}\text { Spleen } \\
\text { mass, g }\end{array}$ & $\begin{array}{l}\text { Spleen } \\
\text { index }\end{array}$ & $\begin{array}{l}\text { Kidney } \\
\text { mass, g }\end{array}$ & $\begin{array}{l}\text { Kidney } \\
\text { index }\end{array}$ & $\begin{array}{c}\text { Brain } \\
\text { mass, } \mathbf{g}\end{array}$ & $\begin{array}{l}\text { Brain } \\
\text { index }\end{array}$ \\
\hline Control A & 22.88 & 0.961 & 0.0420 & 0.066 & 0.0029 & 0.280 & 0.0122 & 0.445 & 0.0194 \\
\hline Control B & 22.34 & 0.937 & 0.0419 & 0.066 & 0.0030 & 0.267 & 0.0120 & 0.430 & 0.0192 \\
\hline Control C & 20.15 & 0.806 & 0.0400 & 0.065 & 0.0032 & 0.235 & 0.0117 & 0.431 & 0.0214 \\
\hline Control D & 20.78 & 0.842 & 0.0405 & 0.061 & 0.0029 & 0.237 & 0.0114 & 0.409 & 0.0197 \\
\hline $\begin{array}{c}\text { Control } \\
\text { (Ave } \pm \text { SD) }\end{array}$ & $\begin{array}{c}21.54 \pm \\
1.28\end{array}$ & $\begin{array}{c}0.887 \pm \\
0.074\end{array}$ & $\begin{array}{c}0.0411 \pm \\
0.001\end{array}$ & $\begin{array}{c}0.0645 \pm \\
0.002\end{array}$ & $\begin{array}{c}0.0030 \pm \\
0.0001\end{array}$ & $\begin{array}{c}0.2548 \pm \\
0.0223\end{array}$ & $\begin{array}{c}0.0118 \pm \\
0.0004\end{array}$ & $\begin{array}{c}0.4288 \pm \\
0.0148\end{array}$ & $\begin{array}{c}0.0199 \pm \\
0.001\end{array}$ \\
\hline $\mathrm{CIS}, \mathrm{d} 1 \mathrm{~A}$ & 20.00 & 0.968 & 0.0484 & 0.095 & 0.0047 & 0.305 & 0.0153 & 0.397 & 0.0199 \\
\hline $\mathrm{CIS}, \mathrm{d} 1 \mathrm{~B}$ & 18.45 & 0.946 & 0.0513 & 0.087 & 0.0047 & 0.314 & 0.0170 & 0.406 & 0.0220 \\
\hline $\mathrm{CIS}, \mathrm{d} 1 \mathrm{C}$ & 20.12 & 1.040 & 0.0517 & 0.103 & 0.0051 & 0.304 & 0.0151 & 0.430 & 0.0214 \\
\hline $\mathrm{CIS}, \mathrm{d} 1 \mathrm{D}$ & 18.68 & 0.999 & 0.0535 & 0.089 & 0.0048 & 0.265 & 0.0142 & 0.402 & 0.0215 \\
\hline $\begin{array}{c}\text { CIS, d1 } \\
\text { (Ave } \pm \text { SD) }\end{array}$ & $\begin{array}{c}19.31 \pm \\
0.870\end{array}$ & $\begin{array}{c}0.988 \pm \\
0.041\end{array}$ & $\begin{array}{c}0.0512 \pm \\
0.002\end{array}$ & $\begin{array}{c}0.0935 \pm \\
0.007\end{array}$ & $\begin{array}{c}0.0048 \pm \\
0.0002\end{array}$ & $\begin{array}{c}0.2970 \pm \\
0.0218\end{array}$ & $\begin{array}{c}0.0154 \pm \\
0.0012\end{array}$ & $\begin{array}{c}0.4088 \pm \\
0.0146\end{array}$ & $\begin{array}{c}0.0212 \pm \\
0.001\end{array}$ \\
\hline CIS, d7 A & 19.79 & 1.325 & 0.0670 & 0.282 & 0.0142 & 0.402 & 0.0203 & 0.468 & 0.0236 \\
\hline $\mathrm{CIS}, \mathrm{d} 7 \mathrm{~B}$ & 19.70 & 1.308 & 0.0664 & 0.289 & 0.0147 & 0.321 & 0.0163 & 0.408 & 0.0207 \\
\hline $\mathrm{CIS}, \mathrm{d} 7 \mathrm{C}$ & 20.31 & 1.276 & 0.0628 & 0.234 & 0.0115 & 0.313 & 0.0154 & 0.439 & 0.0216 \\
\hline $\begin{array}{c}\text { CIS, d7 } \\
\text { (Ave } \pm \text { SD) }\end{array}$ & $\begin{array}{c}19.93 \pm \\
0.329\end{array}$ & $\begin{array}{l}1.30 \pm \\
0.025\end{array}$ & $\begin{array}{c}0.0654 \pm \\
0.002 \\
\end{array}$ & $\begin{array}{c}0.2683 \pm \\
0.030\end{array}$ & $\begin{array}{c}0.0135 \pm \\
0.0017\end{array}$ & $\begin{array}{c}0.345 \pm \\
0.049\end{array}$ & $\begin{array}{c}0.0173 \pm \\
0.0026\end{array}$ & $\begin{array}{c}0.438 \pm \\
0.030\end{array}$ & $\begin{array}{c}0.0220 \pm \\
0.002\end{array}$ \\
\hline $\mathrm{CIS}, \mathrm{d} 28 \mathrm{~A}$ & 23.52 & 1.183 & 0.0503 & 0.170 & 0.0072 & 0.335 & 0.0142 & 0.456 & 0.0194 \\
\hline $\mathrm{CIS}, \mathrm{d} 28 \mathrm{~B}$ & 21.70 & 0.976 & 0.0450 & 0.173 & 0.0080 & 0.283 & 0.0130 & 0.446 & 0.0206 \\
\hline $\mathrm{CIS}, \mathrm{d} 28 \mathrm{C}$ & 17.67 & 0.919 & 0.0520 & 0.151 & 0.0085 & 0.244 & 0.0138 & 0.386 & 0.0218 \\
\hline CIS, d28 D & 22.21 & 1.188 & 0.0535 & 0.175 & 0.0079 & 0.327 & 0.0147 & 0.464 & 0.0209 \\
\hline $\begin{array}{c}\text { CIS, d28 } \\
\text { (Ave } \pm \text { SD) }\end{array}$ & $\begin{array}{c}21.28 \pm \\
2.52\end{array}$ & $\begin{array}{c}1.07 \pm \\
0.14\end{array}$ & $\begin{array}{c}0.0502 \pm \\
0.004\end{array}$ & $\begin{array}{c}0.1673 \pm \\
0.011\end{array}$ & $\begin{array}{c}0.0079 \pm \\
0.0005\end{array}$ & $\begin{array}{c}0.297 \pm \\
0.042\end{array}$ & $\begin{array}{c}0.0139 \pm \\
0.0007\end{array}$ & $\begin{array}{c}0.438 \pm \\
0.035\end{array}$ & $\begin{array}{c}0.0207 \pm \\
0.001\end{array}$ \\
\hline
\end{tabular}


Table S6 (continued): Body and organ weights and calculated indexes for individual animals and cohorts.

\begin{tabular}{|c|c|c|c|c|c|c|c|c|c|}
\hline Mouse cohort & $\begin{array}{l}\text { Body } \\
\text { mass, } g\end{array}$ & $\begin{array}{l}\text { Liver } \\
\text { mass, } \mathrm{g}\end{array}$ & $\begin{array}{l}\text { Liver } \\
\text { index }\end{array}$ & $\begin{array}{l}\text { Spleen } \\
\text { mass, } \mathrm{g}\end{array}$ & $\begin{array}{c}\text { Spleen } \\
\text { index }\end{array}$ & $\begin{array}{l}\text { Kidney } \\
\text { mass, } g\end{array}$ & $\begin{array}{c}\text { Kidney } \\
\text { index }\end{array}$ & $\begin{array}{l}\text { Brain } \\
\text { mass, } g\end{array}$ & $\begin{array}{l}\text { Brain } \\
\text { index }\end{array}$ \\
\hline CISZ, d1 A & 18.60 & 0.759 & 0.0408 & 0.063 & 0.0034 & 0.213 & 0.0115 & 0.413 & 0.0222 \\
\hline CISZ, d1 B & 20.74 & 0.927 & 0.0447 & 0.079 & 0.0038 & 0.302 & 0.0146 & 0.421 & 0.0203 \\
\hline CISZ, d1 C & 20.62 & 0.998 & 0.0484 & 0.079 & 0.0038 & 0.252 & 0.0122 & 0.429 & 0.0208 \\
\hline CISZ, d1 D & 20.23 & 0.933 & 0.0461 & 0.075 & 0.0037 & 0.276 & 0.0136 & 0.399 & 0.0197 \\
\hline $\begin{array}{c}\text { CISZ, d1 } \\
\text { (Ave } \pm \text { SD) }\end{array}$ & $\begin{array}{c}20.05 \pm \\
0.99\end{array}$ & $\begin{array}{c}0.904 \pm \\
0.10\end{array}$ & $\begin{array}{c}0.0450 \pm \\
0.003\end{array}$ & $\begin{array}{c}0.0740 \pm \\
0.008\end{array}$ & $\begin{array}{c}0.0037 \pm \\
0.0002\end{array}$ & $\begin{array}{c}0.261 \pm \\
0.038\end{array}$ & $\begin{array}{c}0.0130 \pm \\
0.0014\end{array}$ & $\begin{array}{l}0.416 \pm \\
0.0098\end{array}$ & $\begin{array}{c}0.0192 \pm \\
0.001\end{array}$ \\
\hline CISZ, d7 A & 21.67 & 1.075 & 0.0496 & 0.104 & 0.0048 & 0.293 & 0.0135 & 0.424 & 0.0196 \\
\hline CISZ, d7 B & 22.11 & 1.082 & 0.0489 & 0.135 & 0.0061 & 0.305 & 0.0138 & 0.400 & 0.0181 \\
\hline CISZ, d7 C & 21.61 & 1.067 & 0.0494 & 0.121 & 0.0056 & 0.291 & 0.0135 & 0.412 & 0.0191 \\
\hline CISZ, d7 D & 20.71 & 0.946 & 0.0457 & 0.104 & 0.0050 & 0.246 & 0.0119 & 0.410 & 0.0198 \\
\hline CISZ, d7 & $21.53 \pm$ & $1.04 \pm$ & $0.0484 \pm$ & $0.1160 \pm$ & $0.0054 \pm$ & $0.284 \pm$ & $0.0132 \pm$ & $0.412 \pm$ & $0.0192 \pm$ \\
\hline$($ Ave $\pm S D)$ & 0.59 & 0.065 & 0.002 & 0.015 & 0.0006 & 0.026 & 0.0009 & 0.0098 & 0.001 \\
\hline CISZ, d28 A & 23.47 & 1.062 & 0.0452 & 0.131 & 0.0056 & 0.285 & 0.0121 & 0.445 & 0.0190 \\
\hline $\mathrm{CISZ}, \mathrm{d} 28 \mathrm{~B}$ & 21.65 & 0.976 & 0.0451 & 41 & 0.0065 & 0.267 & 0.0123 & 0.430 & \\
\hline $\mathrm{CISZ}, \mathrm{d} 28 \mathrm{C}$ & 19.76 & 0.920 & 0.0466 & 0.138 & 0.0070 & 0.220 & 0.0111 & 0.402 & 0.0203 \\
\hline CISZ, d28 D & 22.14 & 1.048 & 0.0473 & 0.127 & 0.0057 & 0.270 & 0.0122 & 0.450 & 0.0203 \\
\hline $\begin{array}{l}\text { CISZ, d28 } \\
\text { (Ave } \pm \text { SD) }\end{array}$ & $\begin{array}{c}21.76 \pm \\
1.54\end{array}$ & $\begin{array}{l}1.00 \pm \\
0.066\end{array}$ & $\begin{array}{c}0.0461 \pm \\
0.001\end{array}$ & $\begin{array}{c}0.134 \pm \\
0.006\end{array}$ & $\begin{array}{c}0.0062 \pm \\
0.0007\end{array}$ & $\begin{array}{c}0.261 \pm \\
0.28\end{array}$ & $\begin{array}{c}0.0119 \pm \\
0.0006\end{array}$ & $\begin{array}{c}0.432 \pm \\
0.216\end{array}$ & $\begin{array}{c}0.0199 \pm \\
0.001\end{array}$ \\
\hline $\mathrm{CIS} / \mathrm{ZnS}, \mathrm{d} 1 \mathrm{~A}$ & 18.96 & 0.890 & 0.0469 & & & & & & \\
\hline $\mathrm{CIS} / \mathrm{ZnS}, \mathrm{d} 1 \mathrm{~B}$ & & & & & & & & & \\
\hline $\mathrm{CIS} / \mathrm{ZnS}, \mathrm{d} 1 \mathrm{C}$ & 18.86 & 0.968 & & & & & & & \\
\hline $\begin{array}{l}\text { CIS/ZnS, d1 } \\
\text { (Ave } \pm \text { SD) }\end{array}$ & $\begin{array}{c}19.26 \pm \\
0.61\end{array}$ & $\begin{array}{c}0.919 \pm \\
0.042\end{array}$ & $\begin{array}{c}0.0477 \pm \\
0.003\end{array}$ & $\begin{array}{c}0.0583 \pm \\
0.003\end{array}$ & $\begin{array}{c}0.0030 \pm \\
0.0001\end{array}$ & $\begin{array}{c}0.272 \pm \\
0.032\end{array}$ & $\begin{array}{c}0.0141 \pm \\
0.0017\end{array}$ & $\begin{array}{c}0.409 \pm \\
0.017\end{array}$ & $\begin{array}{c}0.0212 \pm \\
0.001\end{array}$ \\
\hline $\mathrm{CIS} / \mathrm{ZnS}, \mathrm{d} 7 \mathrm{~A}$ & 20.38 & 1.107 & 0.0543 & 0.076 & 0.0037 & 0.282 & 0.0138 & 0.428 & 0.0210 \\
\hline CIS/ZnS, d7 B & 21.21 & 1.027 & 0.0484 & 0.079 & 0.0037 & 0.288 & 0.0136 & 0.440 & 0.0207 \\
\hline $\mathrm{ClS} / \mathrm{ZnS}$, d7 C & 21.47 & 0.968 & 0.0451 & 0.061 & 0.0028 & 0.276 & 0.0129 & 0.413 & 0.0192 \\
\hline $\mathrm{CIS} / Z n S$, d7 D & 21.49 & 1.127 & 0.0524 & 0.077 & 0.0036 & 0.283 & 0.0132 & 0.455 & 0.0212 \\
\hline $\begin{array}{l}\text { CIS/ZnS, d7 } \\
\text { (Ave } \pm \text { SD) }\end{array}$ & $\begin{array}{c}21.14 \pm \\
0.52\end{array}$ & $\begin{array}{l}1.06 \pm \\
0.074\end{array}$ & $\begin{array}{c}0.0501 \pm \\
0.004\end{array}$ & $\begin{array}{c}0.0733 \pm \\
0.008\end{array}$ & $\begin{array}{c}0.0035 \pm \\
0.0004\end{array}$ & $\begin{array}{c}0.282 \pm \\
0.005\end{array}$ & $\begin{array}{c}0.0134 \pm \\
0.0004\end{array}$ & $\begin{array}{c}0.434 \pm \\
0.018\end{array}$ & $\begin{array}{c}0.0205 \pm \\
0.001\end{array}$ \\
\hline $\mathrm{ClS} / \mathrm{ZnS}, \mathrm{d} 28 \mathrm{~A}$ & 24.13 & 1.006 & 0.0417 & 0.076 & 0.0031 & 0.294 & 0.0122 & 0.450 & 0.0186 \\
\hline $\mathrm{CIS} / \mathrm{ZnS}, \mathrm{d} 28 \mathrm{~B}$ & 23.47 & 0.970 & 0.0413 & 0.075 & 0.0032 & 0.295 & 0.0126 & 0.456 & 0.0194 \\
\hline $\mathrm{CIS} / \mathrm{ZnS}, \mathrm{d} 28 \mathrm{C}$ & 22.37 & 0.914 & 0.0409 & 0.078 & 0.0035 & 0.300 & 0.0134 & 0.450 & 0.0201 \\
\hline $\mathrm{CIS} / \mathrm{ZnS}, \mathrm{d} 28 \mathrm{D}$ & 25.91 & 1.133 & 0.0437 & 0.081 & 0.0031 & 0.314 & 0.0121 & 0.458 & 0.0177 \\
\hline CIS/ZnS, d28 & $23.97 \pm$ & $1.01 \pm$ & $0.0419 \pm$ & $0.0775 \pm$ & $0.0032 \pm$ & $0.301 \pm$ & $0.0126 \pm$ & $0.454 \pm$ & $0.0190 \pm$ \\
\hline (Ave \pm SD) & 1.48 & 0.093 & 0.001 & 0.003 & 0.0002 & 0.009 & 0.0006 & 0.004 & 0.001 \\
\hline
\end{tabular}




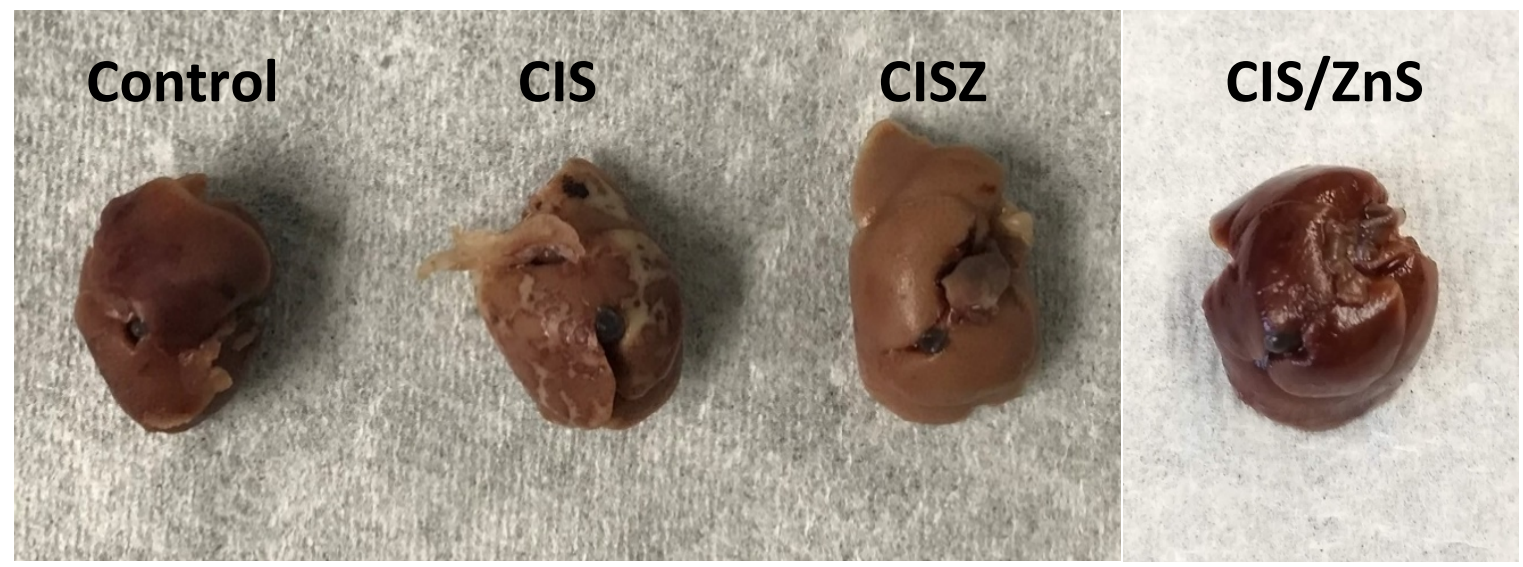

Figure S7: Photograph of livers post fixation. Photo of livers from control (far left), CIS (center left), CISZ (center right), and CIS/ZnS (far right) dosed mice (12 mg/kg), post fixation, sacrificed at day 3 (photos not equally scaled). Notice the necrotic regions across the CIS liver.

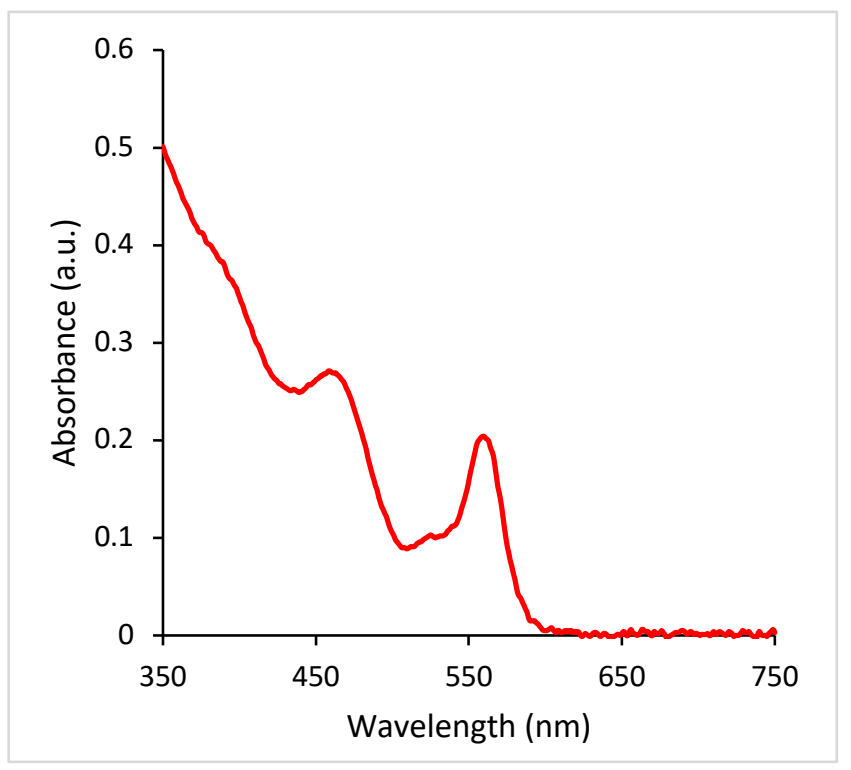

Figure S8: Absorbance of CdSe cores. Particle diameter ( $3.21 \mathrm{~nm}$ ) was determined using the position of the $1 \mathrm{~s}$ peak $(558 \mathrm{~nm})$ through the equation in Yu et al. ${ }^{12}$ 
Table S7: Blood biochemistry values for individual animals and cohorts.

\begin{tabular}{|c|c|c|c|c|c|c|c|}
\hline Mouse cohort & ALT & AST & BUN & Mouse cohort & ALT & AST & BUN \\
\hline Control A & 52 & 42 & 6 & CISZ, d28 A & 80 & 96 & 10 \\
\hline Control B & 46 & 88 & 18 & CISZ, d28 B & 86 & 90 & 12 \\
\hline Control C & 44.8 & 87.5 & 12.8 & CISZ, d28 C & 72 & 102 & 18 \\
\hline Control D & 66.1 & 74.7 & 14.9 & CISZ, d28 D & 84 & 102 & 8 \\
\hline Control & 52.2 & 73.0 & 12.9 & CISZ, d28 & 80.5 & 97.5 & 12.0 \\
\hline (Ave \pm SD) & \pm 9.8 & \pm 21.6 & \pm 5.1 & (Ave \pm SD) & \pm 6.2 & \pm 5.7 & \pm 4.3 \\
\hline $\mathrm{CIS}, \mathrm{d} 1 \mathrm{~A}$ & 214 & 358 & 8 & $\mathrm{CIS} / \mathrm{ZnS}, \mathrm{d} 1 \mathrm{~A}$ & 692 & 2816 & 41.6 \\
\hline CIS, d1 B & 5832 & 7232 & 14 & $\mathrm{CIS} / \mathrm{ZnS}, \mathrm{d} 1 \mathrm{~B}$ & 1674 & 826 & 9.75 \\
\hline CIS, d1 C & 2000 & 1988 & 12 & $\mathrm{CIS} / \mathrm{ZnS}, \mathrm{d} 1 \mathrm{C}$ & 401 & 1255 & 22.3 \\
\hline CIS, d1 D & 1878 & 1654 & 14 & CIS/ZnS, d1 & 693.2 & 1225.6 & 19.5 \\
\hline CIS, d1 & 2481.0 & 2808.0 & 12.0 & (Ave \pm SD) & \pm 711.5 & $\begin{array}{c} \pm \\
1180.1 \\
\end{array}$ & \pm 16.5 \\
\hline (Ave \pm SD) & \pm 2377.9 & \pm 3032.0 & \pm 2.8 & $\mathrm{CIS} / \mathrm{ZnS}, \mathrm{d} 7 \mathrm{~A}$ & 59.2 & 95.3 & 27.4 \\
\hline CIS, d7 A & 144 & 300 & 16 & $\mathrm{CIS} / \mathrm{ZnS}, \mathrm{d} 7 \mathrm{~B}$ & 18.6 & 174.6 & 26.0 \\
\hline CIS, d7 B & 162 & 436 & 16 & CIS/ZnS, d7 C & 48.1 & 71.5 & 18.2 \\
\hline CIS, d7 C & 126 & 250 & 16 & CIS/ZnS, d7 D & 50.0 & 126.9 & 16.2 \\
\hline CIS, d7 & 702.5 & 1004.5 & 12.7 & CIS/ZnS, d7 & 44.0 & 117.1 & 22.0 \\
\hline (Ave \pm SD) & \pm 1117.1 & \pm 1353.9 & \pm 6.6 & (Ave \pm SD) & \pm 17.6 & \pm 44.5 & \pm 5.6 \\
\hline $\mathrm{CIS}, \mathrm{d} 28 \mathrm{~A}$ & 66 & 158 & 16 & $\mathrm{CIS} / \mathrm{ZnS}, \mathrm{d} 28 \mathrm{~A}$ & 37.3 & 70.1 & 15.8 \\
\hline $\mathrm{CIS}, \mathrm{d} 28 \mathrm{~B}$ & 96 & 180 & 14 & $\mathrm{CIS} / \mathrm{ZnS}, \mathrm{d} 28 \mathrm{~B}$ & 52 & 64 & 14 \\
\hline CIS, d28 C & 70 & 184 & 14 & $\mathrm{CIS} / \mathrm{ZnS}, \mathrm{d} 28 \mathrm{C}$ & 30 & 55 & 14 \\
\hline CIS, d28 D & 92 & 162 & 10 & $\mathrm{CIS} / \mathrm{ZnS}, \mathrm{d} 28 \mathrm{D}$ & 39.0 & 66.4 & 15.9 \\
\hline CIS, d28 & 81.0 & 171.0 & 13.5 & CIS/ZnS, d28 & 39.6 & 63.9 & 14.9 \\
\hline (Ave \pm SD) & \pm 15.2 & \pm 12.9 & \pm 2.5 & (Ave \pm SD) & \pm 9.2 & \pm 6.4 & \pm 1.1 \\
\hline CISZ, d1 A & & & & UbiQD CIS A & 99.7 & 148.8 & 14.4 \\
\hline CISZ, d1 B & 60 & 96 & 14 & UbiQD CIS B & 98.2 & 193.6 & 13.0 \\
\hline CISZ, d1 C & 80 & 146 & 10 & UbiQD CIS C & 109.2 & 164.3 & 20.0 \\
\hline CISZ, d1 D & 92 & 168 & 14 & UbiQD CIS D & & & \\
\hline CISZ, d1 & 77.3 & 136.7 & 12.7 & UbIQD CIS & 102.4 & 168.9 & 15.8 \\
\hline (Ave \pm SD) & \pm 16.2 & \pm 36.9 & \pm 2.3 & (Ave \pm SD) & \pm 5.9 & \pm 22.7 & \pm 3.7 \\
\hline CISZ, d7 A & 144 & 212 & 14 & UbiQD CIS/ZnS A & 73.7 & 101.8 & 8.7 \\
\hline CISZ, d7 B & 102 & 256 & 16 & UbiQD CIS/ZnS B & 56.9 & 60.2 & 14.6 \\
\hline CISZ, d7 C & 112 & 166 & 18 & UbiQD CIS/ZnS C & 36.4 & 75.4 & 18.2 \\
\hline CISZ, d7 D & 134 & 248 & 18 & UbiQD CIS/ZnS D & 62.9 & 74.0 & 18.5 \\
\hline CISZ, d7 & 123.0 & 220.5 & 16.5 & UbIQD CIS/ZnS & 57.5 & 77.8 & 15.0 \\
\hline (Ave \pm SD) & \pm 19.4 & \pm 41.1 & \pm 1.9 & (Ave \pm SD) & \pm 15.7 & \pm 17.4 & \pm 4.6 \\
\hline
\end{tabular}


Table S7 (continued): Blood biochemistry values for individual animals and cohorts.

\begin{tabular}{cccc}
\hline Mouse cohort & ALT & AST & BUN \\
\hline CdSe A & 42.9 & 66.3 & 15.6 \\
CdSe B & 59.4 & 74.3 & 18.6 \\
CdSe C & & & \\
CdSe D & 52.0 & 89.5 & 17.3 \\
\hline CdSe & $\mathbf{5 1 . 4}$ & $\mathbf{7 6 . 7}$ & $\mathbf{1 7 . 2}$ \\
(Ave \pm SD) & $\mathbf{\pm 8 . 3}$ & $\mathbf{\pm 1 1 . 8}$ & $\mathbf{\pm 1 . 5}$ \\
\hline
\end{tabular}

\section{Statistical analysis of ALT values.}

One-way ANOVA statistical analysis is performed to determine whether the mean ALT values for each of the cohorts are statistically similar. Our high calculated F-value $(25.9, p<0.0001$, Table S10) indicates that the group means are not all equivalent. Subsequent pairwise comparisons via non-parametric Games-Howell post hoc test (Table S11) distinguish between significant and insignificant differences in the means of two groups. Games-Howell was used, as it does not assume equal variances and sample sizes. Based on these comparisons, the cohorts naturally separate into two groups comprising animals exhibiting normal and elevated ALT values, respectively. The cohorts in the normal ALT group (Control, CIS/ZnS, and UbiQD CIS/ZnS) all exhibit statistically equal mean ALT values. Likewise, the elevated mean ALT values exhibited by the cohorts in second group (CIS, UbiQD CIS, and CISZ) are statistically equivalent to each other. Each of the cohorts in the first group exhibit statistically different mean ALTs compared to each of the cohorts in the second group. Thus, the CIS particles without a ZnS shell each induce statistically significant elevations in ALT compared to controls and ZnS-shelled particles (or CdSe), but none of those particles is more or less toxic by this metric than the others.

Table S8: ANOVA Single Factor for ALT values.

\begin{tabular}{lrlrrrrrr} 
DESCRIPTION & \multicolumn{1}{c}{ Alpha } & \multicolumn{1}{c}{0.05} \\
\hline \hline \multicolumn{1}{c}{ Group } & Count & Sum & Mean & Variance & \multicolumn{1}{c}{ SS } & Std Err & Lower & \multicolumn{1}{c}{ Upper } \\
\hline Control & 4 & 208.9 & 52.2 & 95.8 & 287.4 & 7.392 & 36.70 & 67.76 \\
UbiQD CIS & 3 & 307.1 & 102.4 & 35.4 & 70.8 & 8.535 & 84.42 & 120.29 \\
CIS & 3 & 432.0 & 144.0 & 324.0 & 648.0 & 8.535 & 126.07 & 161.93 \\
UbiQD CIS/ZnS & 4 & 229.9 & 57.5 & 245.4 & 736.1 & 7.392 & 41.94 & 73.00 \\
CIS/ZnS & 4 & 175.8 & 44.0 & 310.2 & 930.6 & 7.392 & 28.43 & 59.49 \\
CdSe & 3 & 154.3 & 51.4 & 68.5 & 137.0 & 8.535 & 33.51 & 69.37 \\
CISZ & 4 & 492.0 & 123.0 & 374.7 & 1124.0 & 7.392 & 107.47 & 138.53 \\
\hline
\end{tabular}

\begin{tabular}{lrrrcrcrc}
\multicolumn{1}{c}{ Sources } & \multicolumn{1}{c}{ SS } & \multicolumn{1}{c}{$d f$} & \multicolumn{1}{c}{ MS } & $F$ & P value & F crit & RMSSE & \multicolumn{1}{c}{ Sq } \\
\hline Between Groups & 33940.5 & 6 & 5656.7 & 25.884 & $\mathbf{6 . 3 6 E - 0 8}$ & 2.6613 & 2.7349 & 0.8566 \\
Within Groups & 3933.8 & 18 & 218.5 & & & & & \\
Total & 37874.3 & 24 & 1578.1 & & & & & \\
\hline
\end{tabular}


Table S9: Games Howell post-hoc test for ALT values.

Q TEST

\begin{tabular}{llccccccc}
\hline group 1 & group 2 & mean & std err & $q$-stat & $d f$ & $q$-crit & $p$-value & \\
\hline Control & ubiQD CIS & 50.12 & 4.228 & 11.855 & 4.900 & 6.389 & $3.65 \mathrm{E}-03$ & $* * *$ \\
Control & CIS & 91.77 & 8.122 & 11.298 & 2.891 & 8.778 & $2.50 \mathrm{E}-02$ & $*$ \\
Control & ubiQD CIS/ZnS & 5.236 & 6.530 & 0.802 & 5.033 & 6.313 & $9.95 \mathrm{E}-01$ & \\
Control & CIS/ZnS & 8.273 & 7.124 & 1.161 & 4.692 & 6.520 & $9.71 \mathrm{E}-01$ & \\
Control & CdSe & 0.796 & 4.837 & 0.165 & 4.843 & 6.424 & $1.00 \mathrm{E}+00$ & \\
Control & CISZ & 70.77 & 7.669 & 9.228 & 4.440 & 6.695 & $1.48 \mathrm{E}-02$ & $*$ \\
ubiQD CIS & CIS & 41.65 & 7.740 & 5.381 & 2.432 & 10.327 & $1.95 \mathrm{E}-01$ & \\
ubiQD CIS & ubiQD CIS/ZnS & 44.89 & 6.047 & 7.422 & 4.041 & 7.016 & $4.13 \mathrm{E}-02$ & $*$ \\
ubiQD CIS & CIS/ZnS & 58.39 & 6.684 & 8.737 & 3.849 & 7.221 & $2.63 \mathrm{E}-02$ & $*$ \\
ubiQD CIS & CdSe & 50.92 & 4.162 & 12.235 & 3.631 & 7.487 & $9.77 \mathrm{E}-03$ & $* *$ \\
ubiQD CIS & CISZ & 20.65 & 7.262 & 2.843 & 3.715 & 7.381 & $5.20 \mathrm{E}-01$ & \\
CIS & ubiQD CIS/ZnS & 86.53 & 9.202 & 9.404 & 4.047 & 7.011 & $1.78 \mathrm{E}-02$ & $*$ \\
CIS & CIS/ZnS & 100.04 & 9.632 & 10.386 & 4.393 & 6.729 & $9.52 \mathrm{E}-03$ & $* *$ \\
CIS & CdSe & 92.56 & 8.088 & 11.444 & 2.810 & 9.014 & $2.60 \mathrm{E}-02$ & $*$ \\
CIS & CISZ & 21.00 & 10.042 & 2.091 & 4.644 & 6.551 & $7.49 \mathrm{E}-01$ & \\
ubiQD CIS/ZnS & CIS/ZnS & 13.51 & 8.333 & 1.621 & 5.919 & 5.925 & $8.92 \mathrm{E}-01$ & \\
ubiQD CIS/ZnS & CdSe & 6.032 & 6.488 & 0.930 & 4.677 & 6.530 & $9.90 \mathrm{E}-01$ & \\
ubiQD CIS/ZnS & CISZ & 65.53 & 8.804 & 7.444 & 5.750 & 5.990 & $1.91 \mathrm{E}-02$ & $*$ \\
CIS/ZnS & CdSe & 7.476 & 7.085 & 1.055 & 4.448 & 6.689 & $9.81 \mathrm{E}-01$ & \\
CIS/ZnS & CISZ & 79.04 & 9.252 & 8.543 & 5.947 & 5.914 & $8.97 \mathrm{E}-03$ & $* *$ \\
CdSe & CISZ & 71.56 & 7.632 & 9.376 & 4.261 & 6.831 & $1.56 \mathrm{E}-02$ & $*$ \\
\hline
\end{tabular}

${ }^{*}: p<0.05,{ }^{* *}: p<0.01,{ }^{* * *}: p<0.005$ 

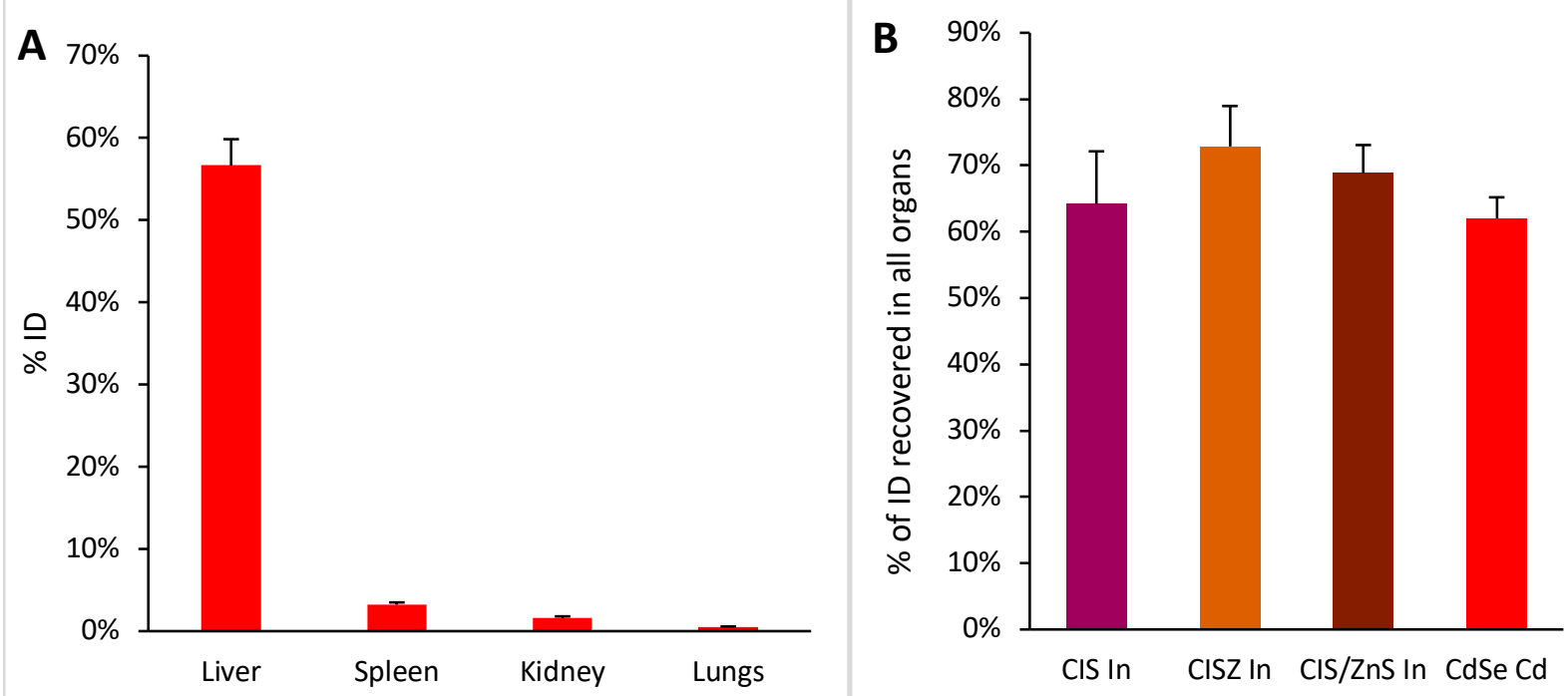

Figure S9: Biodistribution of CdSe Qds at day 7 (A) Distribution in different organs (B) Comparison of total dose recovered of CIS, CISZ, CIS/ZnS, and CdSe at day 7.

\section{A}

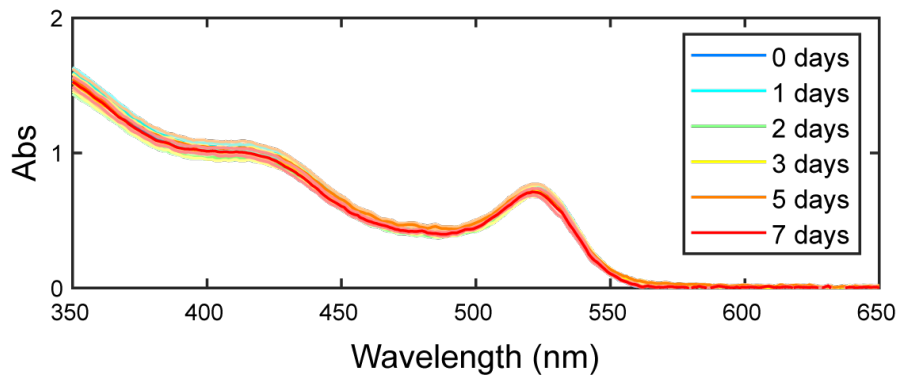

B
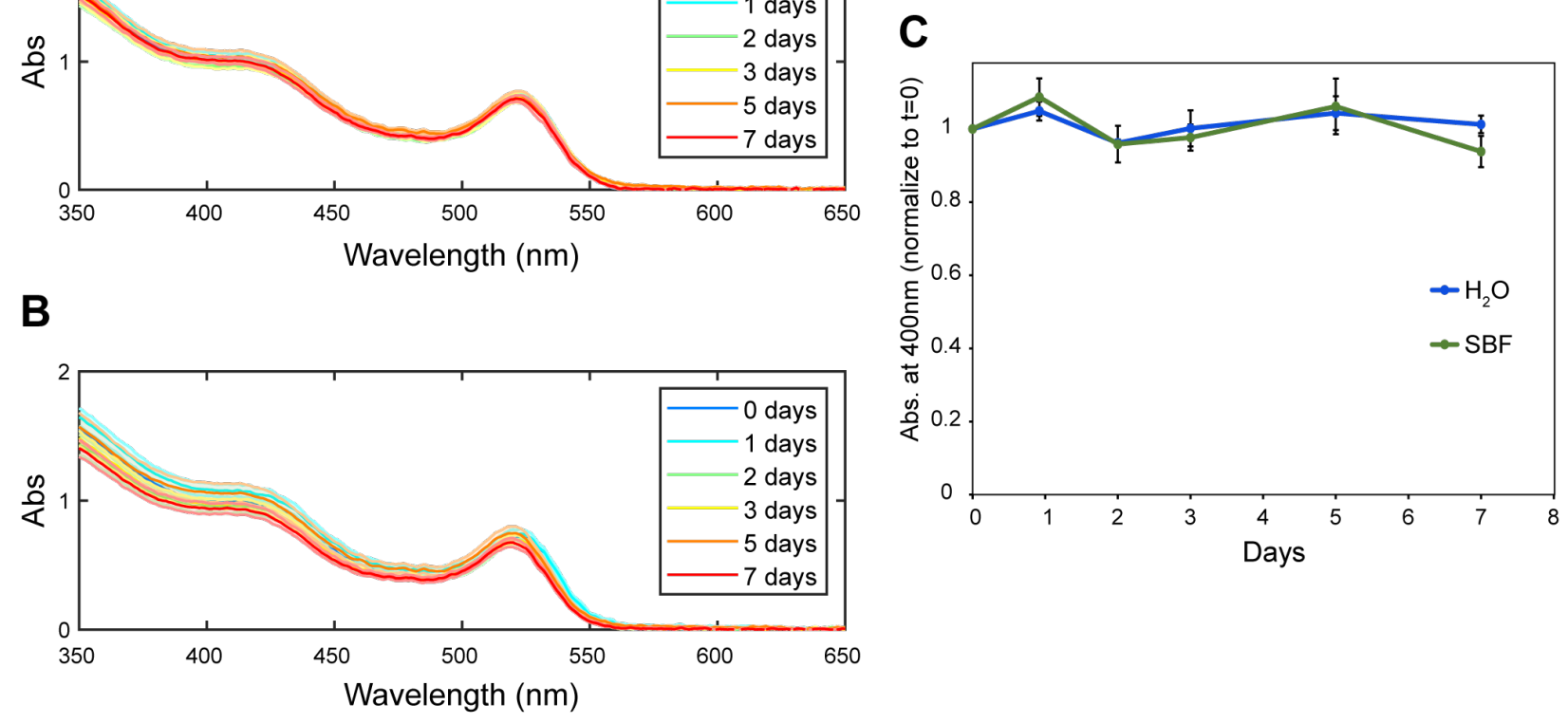

Figure S10: In vitro degradation of DSPE-PEG2k encapsulated CdSe cores (A) Degradation in water at $45^{\circ} \mathrm{C}$ (B) Degradation in Simulated Biological fluid (SBF) at $45^{\circ} \mathrm{C}$. (C) Absorbance at 400 $\mathrm{nm}$ normalized to day 0 . Artificial Lysosomal Fluid (ALF) was not included due to visible aggregation for this specific system, starting at day two. 


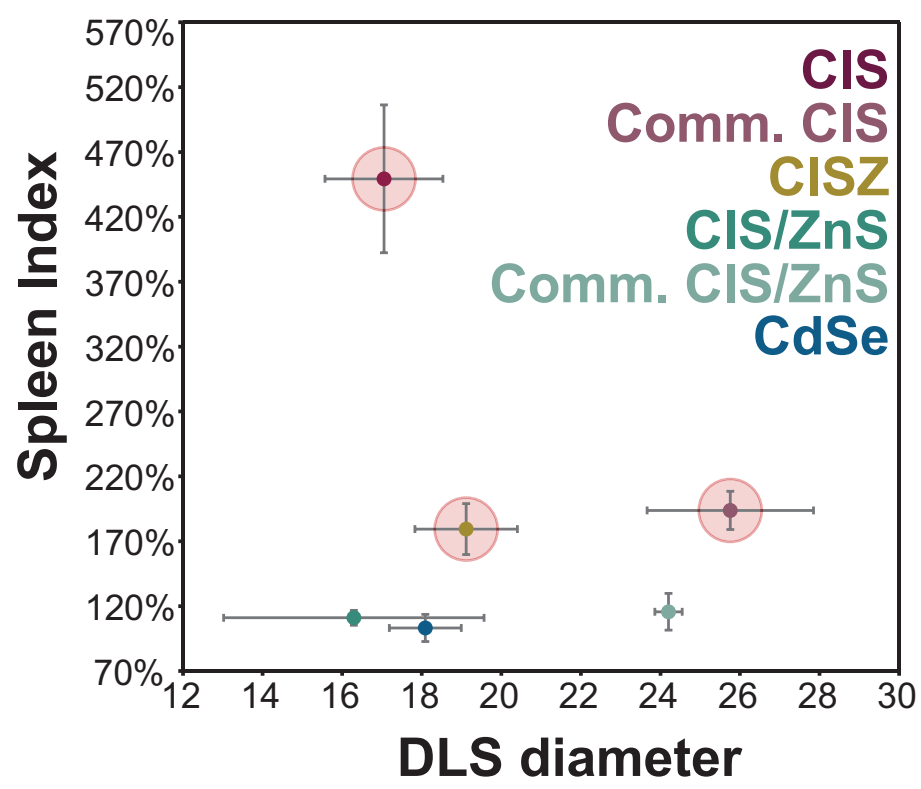

Figure S11: Spleen index from mice dosed with various micelle-encapsulated QDs plotted against their hydrodynamic diameter in nanometers, as determined by dynamic light scattering (DLS). The three samples with the red circle have statistically different spleen index than the control.

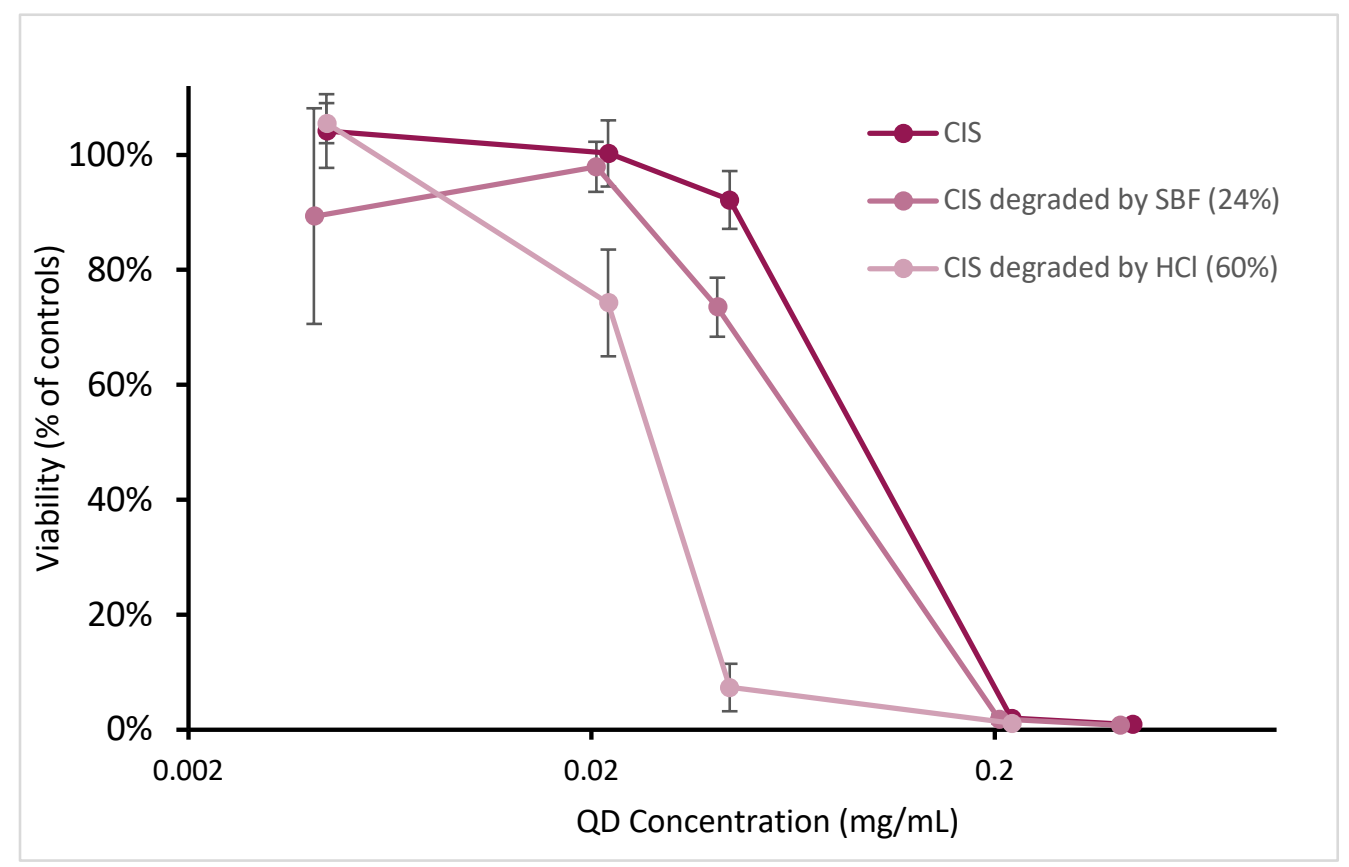

Figure S12: Impact of degraded CIS on viability. Plots of viability vs concentration ( $n=4$ wells per concentration) for CIS, partially (24\%) degraded CIS via SBF incubation, and more degraded (60\%) CIS via acid degradation. All solutions were titrated back to neutral and have been normalized to control solutions of the same titrations/buffers without QDs. 


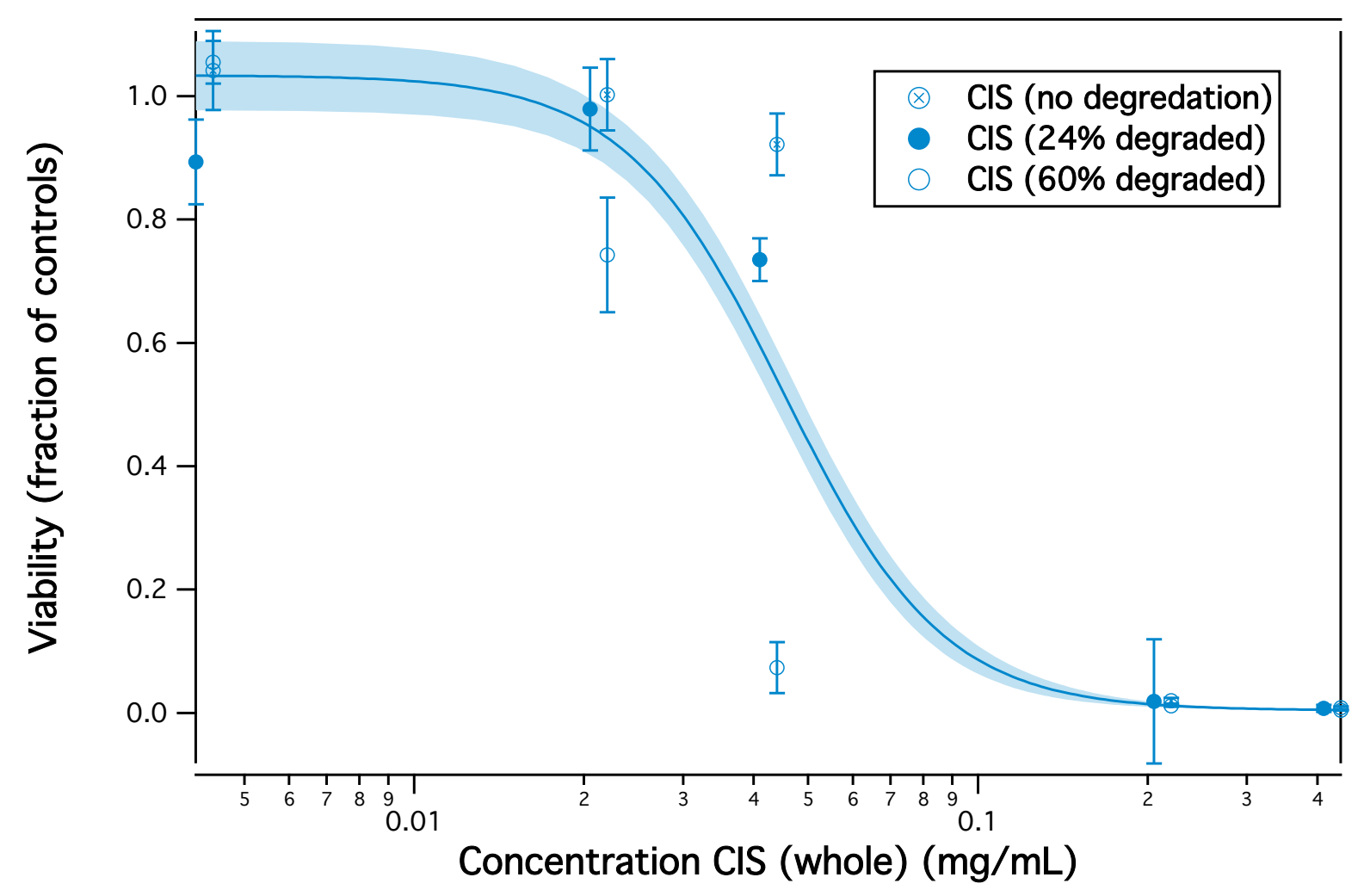

Figure S13: Dose response curve derived from viability assays using whole and partially degraded CIS particles (using $\mathrm{mg} / \mathrm{mL}$ of whole particle) fit to a 4-parameter Hill equation; shaded region indicates the $95 \%$ confidence interval.

\section{Bibliography}

(1) So, D.; Konstantatos, G. Thiol-Free Synthesized Copper Indium Sulfide Nanocrystals as Optoelectronic Quantum Dot Solids. Chem. Mater. 2015, 27 (24), 8424-8432. https://doi.org/10.1021/acs.chemmater.5b03943.

(2) Pons, T.; Pic, E.; Lequeux, N.; Cassette, E.; Bezdetnaya, L.; Dubertret, B. Cadmium-Free CulnS 2 / ZnS Quantum Dots for Sentinel Lymph Node Imaging with Reduced Toxicity. ACS Nano 2010, 4 (5), 2531-2538. https://doi.org/10.1021/nn901421v.

(3) Ghosh, Y.; Mangum, B. D.; Casson, J. L.; Williams, D. J.; Htoon, H.; Hollingsworth, J. A. New Insights into the Complexities of Shell Growth and the Strong Influence of Particle Volume in Nonblinking "Giant" Core/Shell Nanocrystal Quantum Dots. J. Am. Chem. Soc. 2012, 134 (23), 9634-9643. https://doi.org/10.1021/ja212032q. 
(4) Hu, R.; Law, W. C.; Lin, G.; Ye, L.; Liu, J.; Liu, J.; Reynolds, J. L.; Yong, K. T. PEGylated Phospholipid Micelle-Encapsulated near-Infrared PbS Quantum Dots for in Vitro and in Vivo Bioimaging. Theranostics 2012, 2 (7), 723-733. https://doi.org/10.7150/thno.4275.

(5) Malyala, P.; Singh, M. Endotoxin Limits in Formulations for Preclinical Research. J. Pharm. Sci. 2008, 97 (6), 2041-2044. https://doi.org/10.1002/jps.21152.

(6) Copeland, S.; Shaw Warren, H.; Lowry, S. F.; Galvano, S. E.; Remick, D. Acute Inflammatory Response to Endotoxin in Mice and Humans. Clin. Diagn. Lab. Immunol. 2005, 12 (1), 60-67. https://doi.org/10.1128/CDLI.12.1.60-67.2005.

(7) Stopford, W.; Turner, J.; Cappellini, D.; Brock, T. Bioaccessibility Testing of Cobalt Compounds. J. Environ. Monit. 2003, 5 (4), 675-680. https://doi.org/10.1039/b302257a.

(8) Stebounova, L. V.; Guio, E.; Grassian, V. H. Silver Nanoparticles in Simulated Biological Media: A Study of Aggregation, Sedimentation, and Dissolution. J. Nanoparticle Res. 2011, 13 (1), 233-244. https://doi.org/10.1007/s11051-010-0022-3.

(9) Marques, M. R. C.; Loebenberg, R.; Almukainzi, M. Simulated Biological Fluids with Possible Application in Dissolution Testing. Dissolution Technol. 2011, No. August, 15-28. https://doi.org/10.14227/DT180311P15.

(10) Xia, C.; Wu, W.; Yu, T.; Xie, X.; Oversteeg, C. Van; Gerritsen, H. C.; De Mello Donega, C. Size-Dependent Band-Gap and Molar Absorption Coefficients of Colloidal CulnS2 Quantum Dots. ACS Nano 2018. https://doi.org/10.1021/acsnano.8b03641.

(11) Dugan, L.; Leech, L.; Speroni, K. G.; Corriher, J. B. Factors Affecting Hemolysis Rates in Blood Samples Drawn from Newly Placed IV Sites in the Emergency Department. J. Emerg. Nurs. 2005, 31 (4), 338-345. https://doi.org/10.1016/j.jen.2005.05.004.

(12) Yu, W. W.; Qu, L.; Guo, W.; Peng, X. Experimental Determination of the Extinction Coefficient of CdTe, CdSe, and CdS Nanocrystals. Chem. Mater. 2003, 15 (14), 28542860. https://doi.org/10.1021/cm034081k. 